\title{
Merging isotopes and community genomics in a siliceous sinter-depositing hot spring
}

\author{
Jeff R. Havig, ${ }^{1}$ Jason Raymond, ${ }^{2}$ D’Arcy R. Meyer-Dombard, ${ }^{3}$ Natalya Zolotova, ${ }^{1,4}$ \\ and Everett L. Shock ${ }^{1,4}$ \\ Received 30 April 2010; revised 3 September 2010; accepted 21 September 2010; published 22 January 2011.
}

[1] Thermophilic microbes in hydrothermal ecosystems have multiple metabolic strategies for taking up carbon and nitrogen, which may result in distinct stable isotopic compositions of $\mathrm{C}$ and $\mathrm{N}$ in living biomass, as well as other biosignatures that accumulate in the geologic record. Biofilms from "Bison Pool" at Yellowstone National Park display large variations in carbon and nitrogen isotopic values as a function of downstream sampling and illustrate the presence of large shifts in ecological functions as temperature decreases. This is the first study to couple isotopic data with community genomic analysis to predict dominant carbon fixation pathways that create hydrothermal biofilm signatures. The results also suggest nitrogen limitation through the chemotrophic zone and nitrogen fixation in the lower-temperature phototrophic zone.

Citation: Havig, J. R., J. Raymond, D. R. Meyer-Dombard, N. Zolotova, and E. L. Shock (2011), Merging isotopes and community genomics in a siliceous sinter-depositing hot spring, J. Geophys. Res., 116, G01005, doi:10.1029/2010JG001415.

\section{Introduction}

[2] Biofilms can be described as multispecies microbial communities where microbes selectively settle, limit the settlement of other microbes, store nutrients and energy in polymeric structures (called exopolysaccharides), and permit transfer of genetic material horizontally [Watnick and Kolter, 2000]. Biofilms are now understood as the primary mode of being for microbes in natural environments, with functionality ranging from a survival strategy in the case of external stress to an advantageous and mutually beneficial microbial association [Watnick and Kolter, 2000; Pulcini, 2001; Jefferson, 2004; Nikolaev and Plakunov, 2007; Justice et al., 2008]. Biofilms are common in aquatic ecosystems, and those in hot spring outflow channels can exhibit abrupt shifts in microbial composition and biogeochemical processes as temperature and chemical composition change. In fact, as temperature and chemical composition change down a hot spring outflow channel, many biofilms exhibit dramatic changes in density, texture, and pigmentation. One characteristic that is similar among all chemotrophic and phototrophic biofilms in siliceous-sinter depositing hot springs is

\footnotetext{
${ }^{1}$ School of Earth and Space Exploration, Arizona State University, Tempe, Arizona, USA.

${ }^{2}$ School of Natural Sciences, University of California, Merced, California, USA.

${ }^{3}$ Department of Earth and Environmental Sciences, University of Illinois at Chicago, Chicago, Illinois, USA.

${ }^{4}$ Department of Chemistry and Biochemistry, Arizona State University, Tempe, Arizona, USA.
}

Copyright 2011 by the American Geophysical Union. 0148-0227/11/2010JG001415 that they are composed primarily of inorganic constituents ( $>75 \%$ dry weight amorphous silica) intimately interwoven with microbial biomass [Havig, 2009].

[3] The compositions of biofilm communities are influenced by the environment in which they live in and how they uptake and use elements such as carbon and nitrogen. For decades, researchers have studied carbon fixation [Castenholz, 1969; Brock, 1978; Estep, 1984; Macko and Estep, 1984; Madigan et al., 1989; van der Meer et al., 2000a, 2000b; Jahnke et al., 2001; Hugler et al., 2007; Boyd et al., 2009] and nitrogen fixation [Wickstrom, 1980; Estep and Macko, 1984; Steunou et al., 2006] by thermophilic microbial communities, as well as community genomics [Stahl et al., 1985; Barns et al., 1994; Ferris et al., 1996; Reysenbach et al., 2000; Blank et al., 2002; Meyer-Dombard et al., 2005; Ward et al., 2006]. The next step is to directly connect geochemical analyses with community genomics.

[4] Carbon isotopes are fractionated depending upon the carbon fixation pathway used by autotrophic microorganisms. Nitrogen isotopic values of biofilms are driven by several factors, depending upon the source of nitrogen, and whether there is nitrogen limitation or $\mathrm{N}_{2}$ fixation. Changes can be dramatic as documented by Estep [1984] and Estep and Macko [1984], which are summarized in Figure 1 along with other carbon and nitrogen isotopic data from more recent literature sources [van der Meer et al., 2000a; Jahnke et al., 2001; van der Meer et al., 2003; Zhang et al., 2004; van der Meer et al., 2005; van der Meer et al., 2007]. The data in Figure 1 show the fractionation of carbon isotopes and the nitrogen isotopic composition plotted against temperature for biofilms collected from hot springs in Yellowstone National Park. Carbon isotopic values are given as isotopic ratios of ${ }^{13} \mathrm{C}$ to ${ }^{12} \mathrm{C}$ from the equation $\left[\left({ }^{13} \mathrm{C} /{ }^{12} \mathrm{C}\right.\right.$ of sample $) /\left({ }^{13} \mathrm{C} /{ }^{12} \mathrm{C}\right.$ of standard $\left.)-1\right] \times 1000$, expressed in delta 

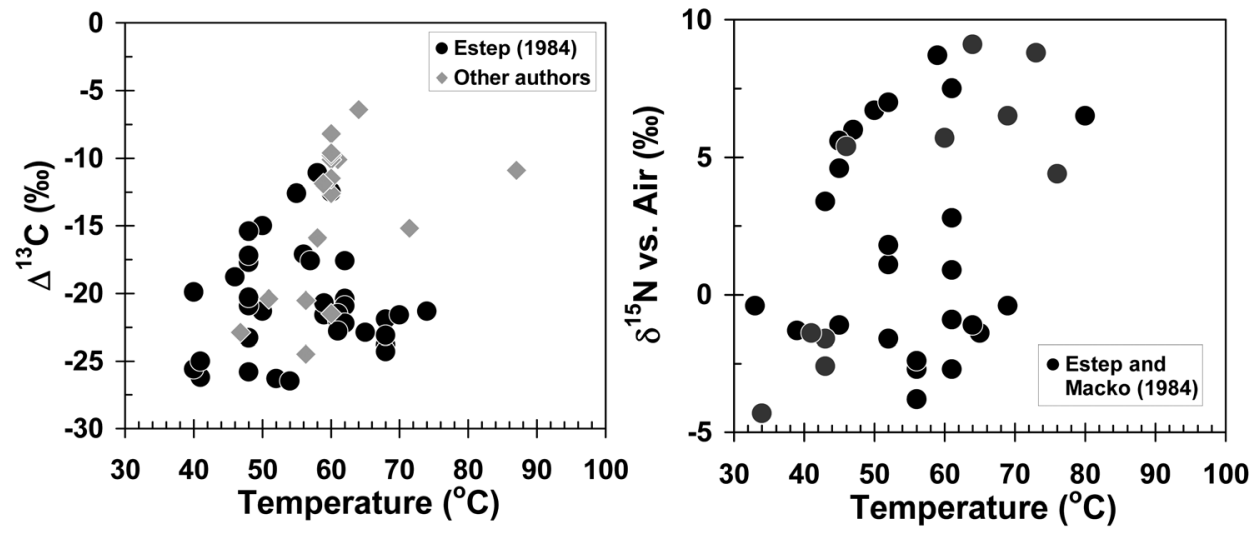

Figure 1. (left) Literature carbon isotope fractionation values and (right) nitrogen isotope values for hot spring biofilms in Yellowstone National Park. Black circles represent values from Estep [1984] and Estep and Macko [1984]; gray diamonds indicate values from other sources [van der Meer et al., 2000a; Jahnke et al., 2001; van der Meer et al., 2003; Zhang et al., 2004; van der Meer et al., 2005; van der Meer et al., 2007].

notation $\left(\delta^{13} \mathrm{C}\right)$, and are reported using the Vienna Pee Dee Belemnite standard, and the nitrogen isotopic values are given as isotopic ratios of ${ }^{15} \mathrm{~N}$ to ${ }^{14} \mathrm{~N}$ from the equation $\left[\left({ }^{15} \mathrm{~N} /{ }^{14} \mathrm{~N}\right.\right.$ of sample $) /\left({ }^{15} \mathrm{~N} /{ }^{14} \mathrm{~N}\right.$ of standard $\left.)-1\right] \times 1000$, expressed in delta notation $\left(\delta^{15} \mathrm{~N}\right)$, with the standard for reporting nitrogen isotopic values being atmospheric $\mathrm{N}_{2}$. Most of the previous work has focused on temperatures below approximately $72^{\circ} \mathrm{C}$ and demonstrate the large range of carbon isotopic fractionations $(-5 \%$ o to $-27 \%$ ) and nitrogen isotopic signatures $(10 \%$ to $-5 \%$ ) found in hydrothermal biofilms. Since the pioneering work by Estep [1984] and Estep and Macko [1984], subsequent studies focused on small sample numbers and species-specific isotopic shifts. van der Meer et al. [2000a] analyzed bulk biofilm samples collected from three sites, two from the New Mound Annex spring in the Mammoth Hydrothermal Area and one from Octopus Spring in the Lower Geyser Basin. Octopus spring was also the focus of research reported by Jahnke et al. [2001] who compared bulk biofilm ${ }^{13} \mathrm{C}$ values with cultured Thermocrinis ruber bulk biomass ${ }^{13} \mathrm{C}$ values grown either autotrophically or heterotrophically as part of a larger study of lipid biomarkers. With the advent of molecular methods in microbial ecology, including metagenomic analysis of whole communities and identification of genes associated with specific $\mathrm{C}$ and $\mathrm{N}$ processes, it is timely to revisit isotopic data from hydrothermal biofilms.

[5] In an effort to understand how internal and external processes affect the composition of hot spring biofilms, we sampled several hot springs with chemotrophic filaments and phototrophic mats in Yellowstone National Park. One of these, called "Bison Pool" (identified as LSMG013 in the Yellowstone National Park Thermal Inventory) was a target of other microbial and geochemical studies [Meyer-Dombard et al., 2005; Windman et al., 2007; Northen et al., 2008; Havig, 2009; Shock et al., 2010; Havig et al., unpublished data; Meyer-Dombard et al., unpublished data] and is the focus of this paper. Comparing isotopic values of biofilms with those of their environmental sources of carbon and nitrogen can reveal the processes by which biofilms uptake and/or fix carbon and nitrogen. Inferences from isotopic data can be coordinated with community genomic data to determine the dominant carbon and nitrogen pathway(s). Estab- lishing how isotopic data reflect biochemical processes in living biofilms will enhance the interpretation of the carbon and nitrogen isotopic values found in the geologic record.

\section{Field Site}

[6] The hot spring investigated in this study is located in Sentinel Meadows, which covers the northwestern portion of the Lower Geyser Basin, Yellowstone National Park, Wyoming (Figure 2). This low-lying meadow system is bounded to the west and north by the $0.108 \mathrm{Ma}$ West Yellowstone Flow rhyolite [Christiansen, 2001]. The meadow features units of siliceous sinter-forming cones, terraces, and aprons around active and inactive hot spring areas, diatomaceous silt deposited from cooling outflow discharge regions of hot springs, and fine-grained humic alluvium that overlies sand and gravel. The meadow is covered by grasses, rushes, wildflowers, and other vegetation. Sentinel Creek passes through and drains the meadow, emptying into the Firehole River to the east. Active hot springs in Sentinel Meadows are typically associated with built-up mounds of silica sinter, boiling at the source, with outflow channels that discharge hydrothermal water with behavior that ranges from continuous and surging to periodic. Inactive hot springs are marked by silica sinter deposits.

[7] "Bison Pool" is a hot spring located in the northern part of Sentinel Meadows, north of Sentinel Creek and northwest of Flat Cone Spring [Meyer-Dombard et al., 2005]. This circum-neutral, boiling, silica-depositing hot spring has a single vent that exhibits a continuous and gently surging outflow discharging into a single channel that empties into the meadow. "Bison Pool" sits atop a low, broad mound made up of silica sinter that is topographically higher $(\sim 2 \mathrm{~m})$ than the surrounding meadow. The source pool is ringed by scalloped silica precipitates and geyserite, silica deposits bound the upper portions of the outflow channel, and the pool and outflow channel have a hardsilica lining that forms an apparently impermeable boundary. The source and outflow channel support filamentous and mat-forming microbial communities ranging from strictly chemotrophic at the higher temperatures $\left(>\sim 68^{\circ} \mathrm{C}\right)$ to phototrophic at the lower temperatures. The hydrothermal water is 


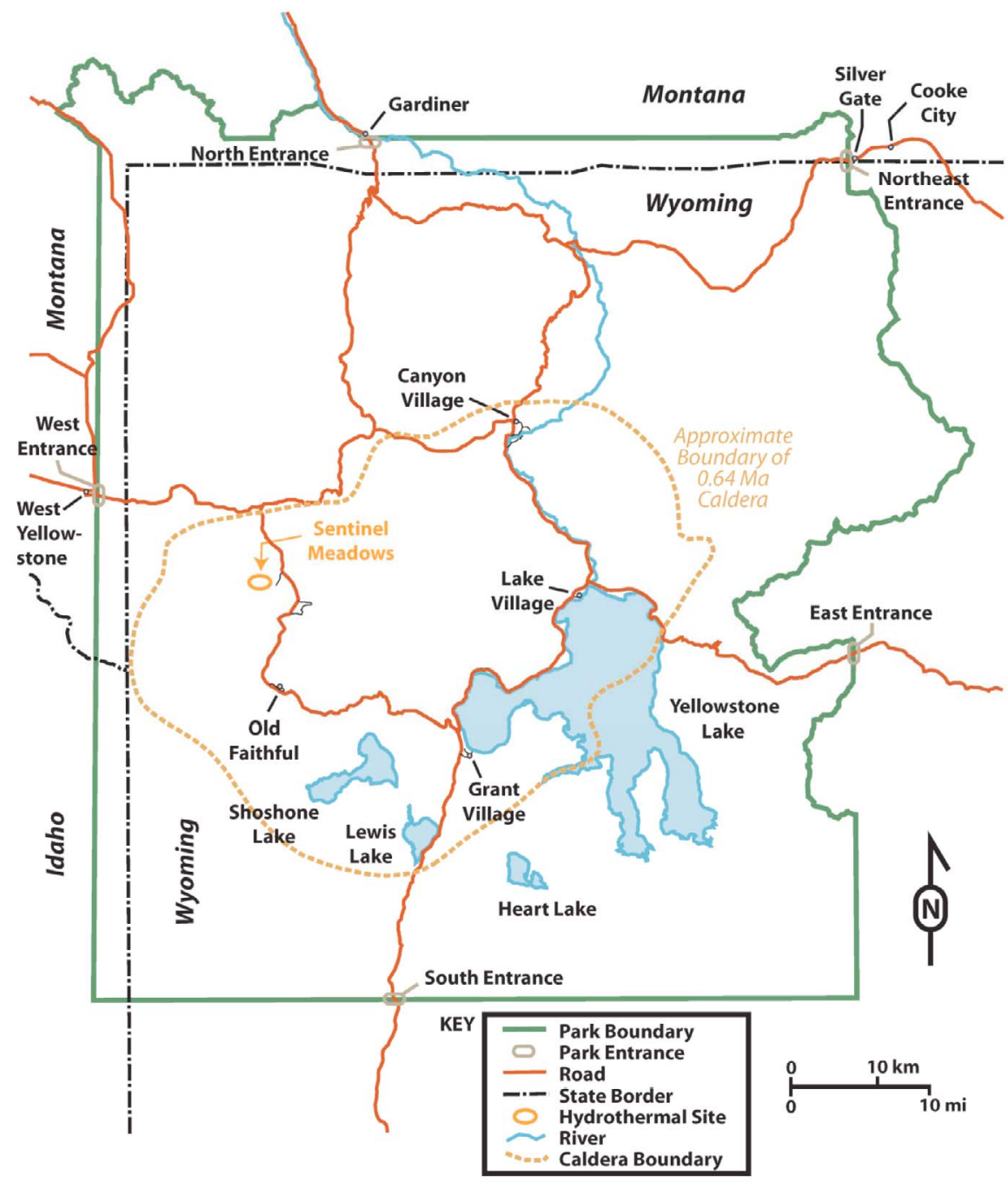

Figure 2. Yellowstone National Park showing the location of Sentinel Meadows. Produced from map provided by the National Park Service.

dominated by dissolved silica, $\mathrm{Na}^{+}, \mathrm{Cl}^{-}$, and bicarbonate. Temperatures at "Bison Pool" range from $93.3^{\circ} \mathrm{C}$ at the source (boiling at the elevation of the meadow) to $\sim 68^{\circ} \mathrm{C}$ at the transition from filamentous chemotrophic to phototrophic communities and continues cooling throughout the photosynthetic mats.

[8] A map of "Bison Pool" and nearby features with sample locations from field work conducted in 2005 and 2006 and a panoramic image showing sampling locations from 2005 are shown in Figure 3. The vegetation (in green) includes grasses (Dichanthelium lanuginosum, Agrostis scabra, Panicum capillare), rushes (Juncus tweedyi), and monkey flower (Mimulus guttatus), as well as various other vascular plant species and mosses. White indicates brecciated siliceous sinter presumably deposited by the outflow channel in the past. The source and upper parts of the hot spring outflow channel shown in blue-gray represent the portions where only chemotrophic communities exist. The downstream portion of the outflow channel shown in yellow, and then orange, represents areas where phototrophic com- munities exist. Yellow represents biofilms that have yellow surfaces and underlying green layers (yellow-green), and orange indicates biofilms composed of upper orange and lower green layers (orange-green). Water and biofilm samples were collected at sites 1-6 in July 2005 and sites 7-13 in August 2006. On the basis of the presence and absence of pigments, it appears that the transition from strictly chemotrophic to mixed phototrophic and chemotrophic communities occurs between sites 3 and 4 (and 10 and 11) (Figure 3a). The panorama (Figure $3 \mathrm{~b}$ ) was compiled from images taken during the 2005 field campaign and spans approximately $90^{\circ}$ from west (left) to north (right).

[9] In general, hot spring biofilms occur primarily as filaments or mats. Filamentous biofilms typically grow as a subaqueous mass that is anchored to a specific location of the pool edge or outflow channel substrate. Mat biofilms cover the bottom of the outflow channel are typically built of several layers and may have filamentous sections growing from the top portion of the mat. Images of biofilm types collected from "Bison Pool" are shown in Figure 4. At the 


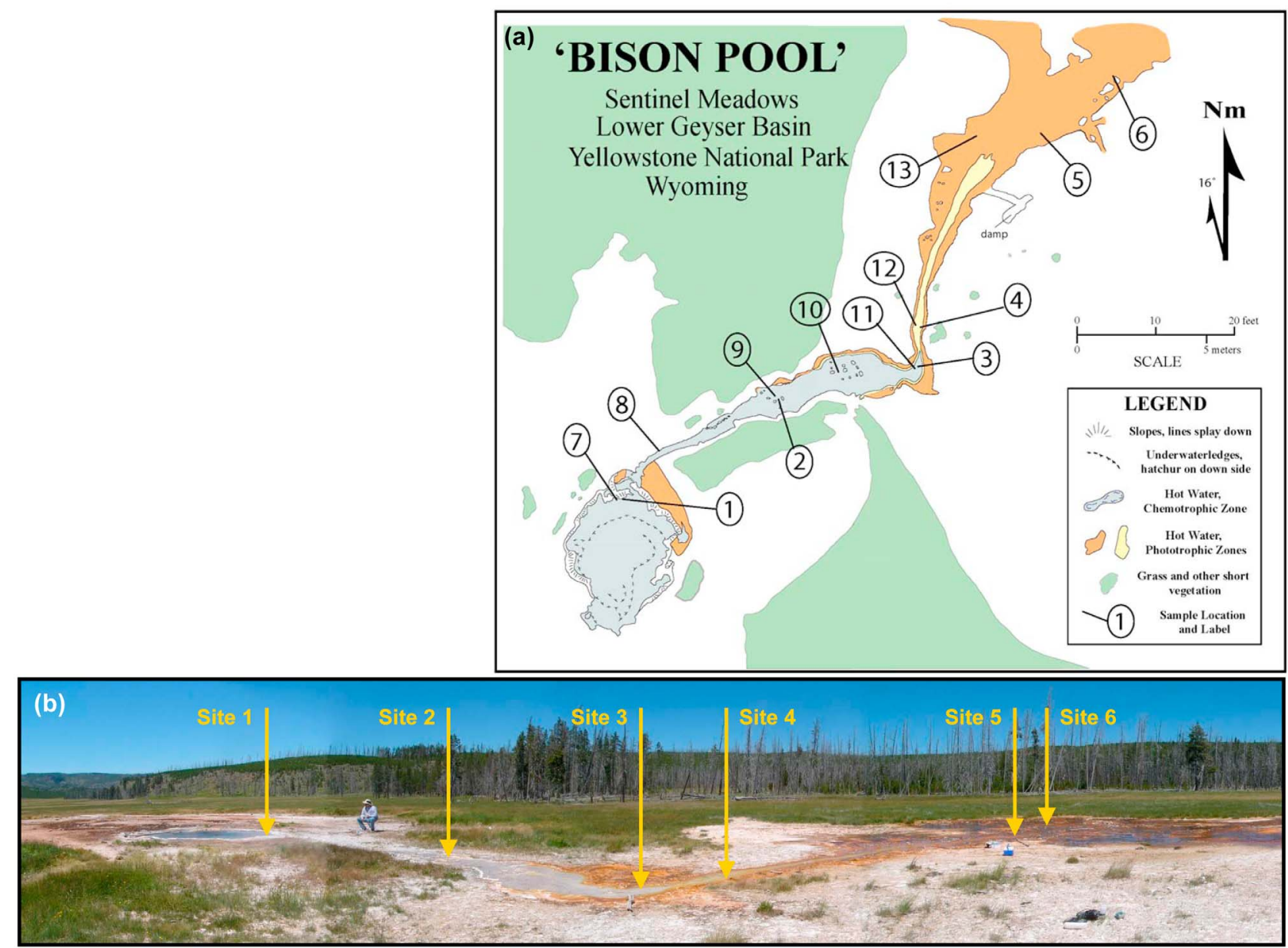

Figure 3. Map and panoramic image of "Bison Pool." (a) Map of "Bison Pool" hot spring showing respective numbered sampling site locations. (b) Panoramic image of "Bison Pool" looking from (left) west to (right) north. Sampling site locations for 2005 (sites 1-6) are indicated for reference to the map.

hot spring source scalloped silica precipitates form around the pool rim (Figure 4a), and translucent white gel and pinkish to beige filamentous biofilms are found on the edges and undersides of the precipitates (Figure 4b). Downstream chemotrophic communities (Figures $4 \mathrm{c}-4 \mathrm{f}$ ) are predominantly filamentous and are pink, beige, pale yellow, or white. The pink filaments (Figure 4c) and yellow filaments (Figure 4d) are found from just upstream of site 2 to halfway between sites 2 and 3 (site 9). Within a $1 \mathrm{~m}$ section centered on site 2 , thicker and more rigid material (Figure 4e) is patchily distributed along the bottom of the outflow channel. White filaments (Figure 4f) are found from halfway between sites 2 and 3 to the photosynthetic fringe, the narrow zone demarking the transition between strictly chemotrophic communities and mixed phototrophic and chemotrophic communities, between sites 3 and 4. Phototrophic communities (Figures $4 \mathrm{~g}$ and $4 \mathrm{~h}$ ) are predominantly mat-forming, with filaments, tubules, tablets, sheets, pillars, warty excrescences, slender spines, and other structures often forming at the mat-water interface. Two visually distinct mat colors can be observed in the outflow channel of "Bison Pool" below $\sim 68^{\circ} \mathrm{C}$. The yellow-green mat (Figure $4 \mathrm{~g}$ ), which is yellow at the top and green below, is found in the middle of the channel from between sites 3 and 4 to approximately $2 \mathrm{~m}$ upstream from site 5. The orange-green mat (Figure $4 \mathrm{~h}$ ), which is orange at the top and green below, is found downstream from the yellow-green mat, and also along the cooler margins of the upper portions of the outflow channel.

\section{Sampling Methodology}

[10] Representative biofilm samples were collected as close as possible to the location where a corresponding water sample was collected. Biofilms in "Bison Pool" typically cover extensive areas. Therefore, several smaller portions of biofilm were collected at each sample site and combined to obtain representative "bulk" biofilm samples. The goal of this sampling method was to minimize the influence of any local anomalies potentially biasing the sample in terms of maturity, concentration, community structure, or other variations. Water samples were taken from the thalweg of the outflow channel (the deepest continuous line along a watercourse, usually with the highest water velocity). This approach was chosen to minimize local effects of cooling or exchange along the borders of the outflow channel. Whether or not differences in morphology were detected, filamentous biofilm samples 


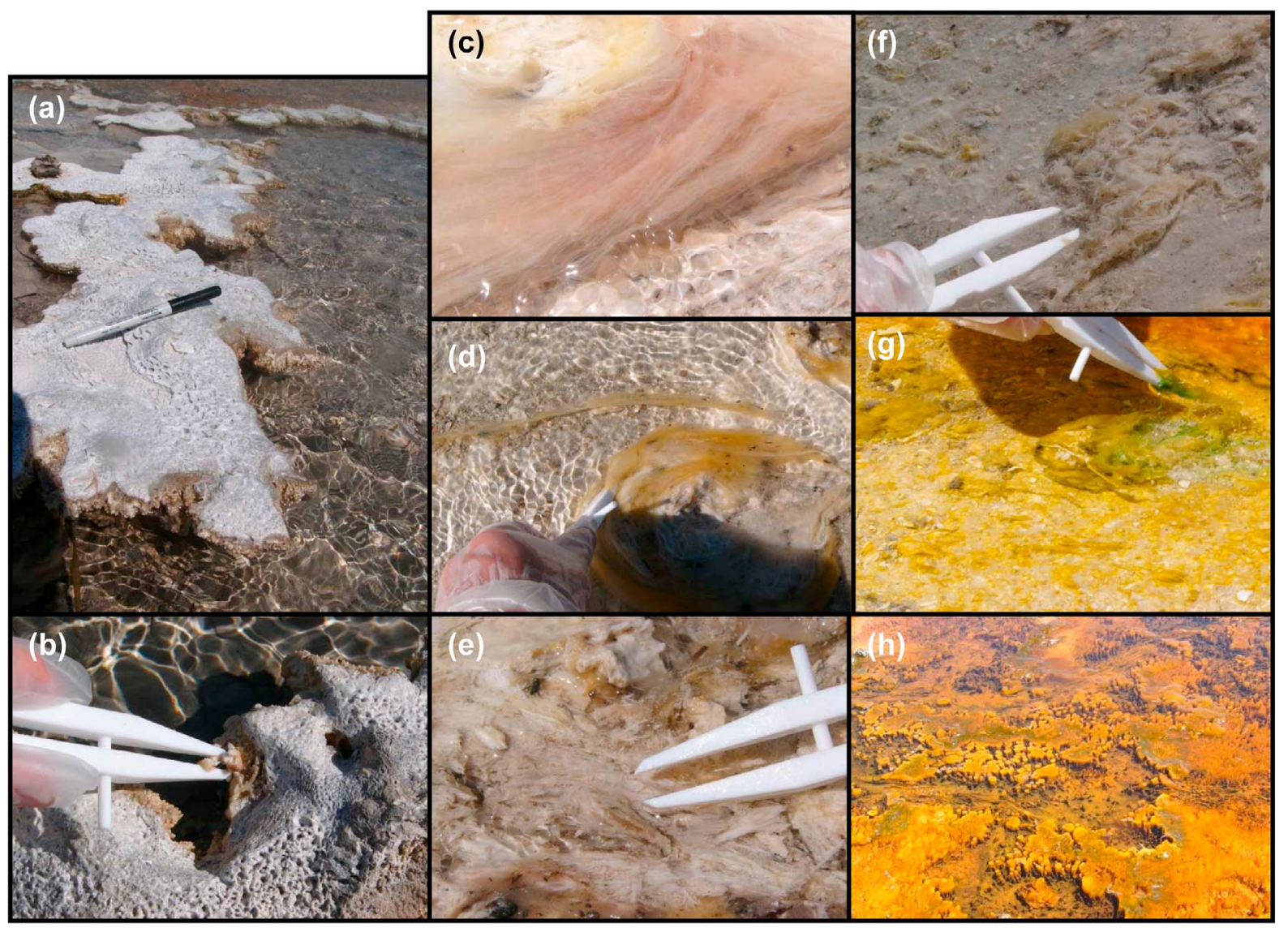

Figure 4. Images of representative biofilms found at "Bison Pool." (a) Image of silica precipitate "scallops" that form around the perimeter of the "Bison Pool" source pool. The pool is on the right in the image, and the outflow empties to the upper left. Note pen for scale. (b) Image of chemotrophic "white goo" and pinkish filamentous biofilms being collected from the underneath edge of silica "scallops." (c) Image of chemotrophic pinkish filamentous biofilm of the type found at sampling sites 2 and 9 . Flow direction is from right to left, and the image field of view is approximately $4 \mathrm{~cm}$. (d) Image of chemotrophic yellowish filamentous biofilm of the type found at sampling sites 2 and 9. Flow direction is from left to right. (e) Image of chemotrophic "crab meat" biofilm of the type found at sampling sites 2 and 9. Flow direction is from left to right. (f) Image of chemotrophic whitish filamentous biofilm of the type found at sampling sites 3, 10, and 11. Flow direction is from left to right. (g) Image of phototrophic yellow-green filamentous and mat biofilm of the type found at sampling sites 4 and 12. Flow direction is from left to right. (h) Image of phototrophic orange-green mat biofilm of the type found at sampling sites 5, 6, and 13. Flow direction is from left to right. Image field of view is approximately $1 \mathrm{~m}$ across.

were collected from multiple locations surrounding the water sample site to allow for the possibility that multiple biofilm communities were present. Biofilm communities exhibiting a physical separation from other communities were separately collected.

\subsection{Collection Techniques}

[11] Biofilms were collected using $150 \mathrm{~mm}$ long, milled teflon tweezers that were prepared by acid washing (soaking in a $10 \%$ solution of trace element clean nitric acid for 3 days) followed by triple rinsing in $18.2 \mathrm{M} \Omega$ deionized (nanopure) $\mathrm{H}_{2} \mathrm{O}$ (Barnstead UV Diamond B-pure nanopure water system) prior to the trip and stored for transport in plastic bags. The tweezers were rinsed with local hot spring water followed by nano-pure DI water between collections from different hot spring sites and rinsed with hot spring sample site water between collection of biofilms from the same site. Samples were collected while wearing vinyl gloves and were placed in plastic containers that had been acid washed and triple-rinsed with nanopure $\mathrm{H}_{2} \mathrm{O}$. Typical samples filled half of a $60 \mathrm{~mL}$ plastic screw-top jar. Samples for metagenomic analysis were collected concurrently with biofilm samples, placed into $15 \mathrm{~mL}$ centrifuge tubes, and immediately stored on ice. Samples were kept on ice the day of collection until they could be stored in a freezer, typically $\sim 6 \mathrm{~h}$ later. Following transport to the laboratory, samples for metagenomic analysis were stored at $-80^{\circ} \mathrm{C}$ until DNA extractions were done. Contextual samples (including vegetation or other biomass, rock, soil, and sinter) were collected in either $50 \mathrm{~mL}$ centrifuge tubes or plastic bags, labeled, 
photographed in place at the time of collection, located using a global positioning instrument, and their locations were marked on maps.

[12] Water was collected from the hot spring using either Pyrex glass media bottles clamped to a collection pole or with long-handled polyethylene dippers $(500 \mathrm{~mL}$ beakers attached to poles). Collectors were rinsed 3 times with sample water before filling. Water was filtered using $0.8 / 0.2 \mu \mathrm{m}$ Supor ${ }^{\circledR}$ syringe filters (Acrodisc ${ }^{\circledR} 32 \mathrm{~mm}$ PF Syringe Filter with $0.8 / 0.2 \mu \mathrm{m}$ Supor ${ }^{\circledR}$ membrane) and collected after flushing the filters with $20 \mathrm{~mL}$ of sample to minimize contamination. Aliquots used for analysis of dissolved organic carbon (DOC) were collected in $40 \mathrm{~mL}$ amber borosilicate vials with silicone Teflon-lined septa and combined with $1 \mathrm{~mL}$ concentrated $\mathrm{H}_{3} \mathrm{PO}_{4}$. Samples for dissolved inorganic carbon (DIC) analysis were also collected in $40 \mathrm{~mL}$ amber borosilicate vials, but with black butyl rubber septa and without acidification. All sample vials were filled to minimize head space and sealed to minimize degassing and atmospheric contamination. Field blanks (18.2 $\mathrm{M} \Omega$ deionized water transported to the field in $1 \mathrm{~L}$ Nalgene bottles) were taken daily using the same equipment and techniques described above. In the field, $\mathrm{pH}$ and temperature were measured with a WTW 330i meter and probe, conductivity and temperature with a YSI 30 conductivity meter and dissolved nitrogen species using Hach DR/2400 Portable Spectrometers with either AccuVac $\AA$ ampuls (for nitrite and nitrate) or AmVer ${ }^{\mathrm{TM}}$ Test'n Tube ${ }^{\mathrm{TM}}$ reactor/cuvette tubes (for dissolved ammonia).

\subsection{Sample Preparation and Analysis}

[13] DOC and DIC concentrations in hydrothermal fluids were measured with an OI Analytical Model 1010 Wet Oxidation TOC Analyzer. After being used to quantify concentrations, $\mathrm{CO}_{2}$ obtained following the reaction of sample with either phosphoric acid (DIC) or sodium persulfate (DOC) was used for isotopic analysis by continuous flow into a Thermo Delta Plus Advantage mass spectrometer. Sampling loops of 1, 5, and $25 \mathrm{~mL}$ volumes were used depending upon sample carbon content, with larger loops required for low-carbon content samples. Data were standardized using three different working standards of glycine with differing isotopic values (low: $\delta^{13} \mathrm{C}=-39.64 \%$, $\delta^{15} \mathrm{~N}=$ $1.35 \%$; mid: $\delta^{13} \mathrm{C}=-8.36 \%$, $\delta^{15} \mathrm{~N}=27.9 \%$; and high: $\delta^{13} \mathrm{C}=15.67 \%$ o, $\delta^{15} \mathrm{~N}=51.8 \%$ ) that encompass expected isotopic variations. The glycine samples were characterized using USGS40 and USGS41 isotopic reference materials.

[14] Biofilms, soil, and sinter were weighed wet, dried in an oven for 3 days at $\sim 90^{\circ} \mathrm{C}$, and then weighed dry. Dried samples were ground with an agate mortar and pestle until uniformly powdered. Samples for $\mathrm{C}$ and $\mathrm{N}$ were weighed and placed into tin dishes, sealed, and analyzed via an Elemental Analyzer Isotope Ratio Mass Spectrometer (EA-IR-MS). A subset of biofilm samples from hot springs throughout Yellowstone that include the range of $\mathrm{pH}$ and temperatures seen at the sample site locations were treated with concentrated $\mathrm{HCl}$ and analyzed to test for changes in carbon or nitrogen content and $\delta^{13} \mathrm{C}$ or $\delta^{15} \mathrm{~N}$ values. The results of this test did not show significant changes in these values (values of acid-treated samples were within $5 \%$ of untreated sample values). As a consequence, it can be safely assumed that no solid carbonate mineral phases are present in the biofilm samples.

[15] Analytical data reported in Table 1 allow comparisons of isotopic signatures of water, biofilms, and contextual samples and calculations of the carbon isotopic fractionations for biofilms. Dissolved inorganic carbon (DIC) and dissolved organic carbon (DOC) are reported as parts per million carbon; $\mathrm{C}$ and $\mathrm{N}$ mass for biofilms are reported as percent of dry weight of sample.

[16] DNA was extracted following the Joint Genome Institute's (JGI) genomic DNA extraction protocol (http:// my.jgi.doe.gov/general/protocols/DNA_Isolation_Bacterial_ CTAB Protocol.doc), but amending the cell breakage step to include an enzymatic digestion using proteinase $\mathrm{K}$ to facilitate biofilm and cell homogenization. Extracted DNA was then shipped on dry ice to JGI for clone library construction and Sanger sequencing. DNA sequence data were analyzed through JGI's IMG/m annotation pipeline for gene identification and sequence annotation and is publicly available through the IMG/m database (http://img.jgi.doe.gov/m/).

\section{Interpretation of Carbon Isotopic Data}

[17] Carbon isotopic fractionation for biofilms is calculated from the difference between the biofilm $\delta^{13} \mathrm{C}$ and DIC $\delta^{13} \mathrm{C}$. Carbon $\delta^{13} \mathrm{C}$ values for samples collected in 2005 and 2006 , as well as the difference between DIC $\delta^{13} \mathrm{C}$ values and biomass $\delta^{13} \mathrm{C}$ values, expressed as large delta ${ }^{13} \mathrm{C}\left(\Delta^{13} \mathrm{C}\right)$ values for both years are depicted in Figure 5. The average DIC concentration was $80 \mathrm{ppm}$ in 2005 , and $62 \mathrm{ppm}$ in 2006. $\delta^{13} \mathrm{C}$ values for DIC increase slightly from the source through the outflow, with values at the source just below $0 \%$ and values in the photosynthetic zone just above $0 \%$ in both 2005 and 2006. In both years, DOC concentrations were below $1 \mathrm{ppm}$. Average DOC $\delta^{13} \mathrm{C}$ values were approximately $-25 \%$ for both years. Analytical precision increased in 2006 due to improvements of analytical techniques. Contextual samples that could act as sources for DOC when they fall into or are blown into the hot spring, including sinter-derived soil, insects, bison fur and excrement, sedges, and meadow soil, all have $\delta^{13} \mathrm{C}$ values that fall within $5 \%$ of the average DOC $\delta^{13} \mathrm{C}$ values.

[18] Biofilm samples collected in 2005 and 2006 demonstrate similar patterns, with the least negative $\delta^{13} \mathrm{C}$ values at the highest temperatures. Values become more negative down the outflow channel, then become slightly less negative as temperatures drop across the photosynthetic mat. Overall trends for 2005 and 2006 biofilm data exhibit the heaviest/ highest values of approximately $-5 \%$ in the temperature range from $93.3^{\circ} \mathrm{C}$ (the source) to about $80^{\circ} \mathrm{C}$. At $\sim 80^{\circ} \mathrm{C}$, biofilm values decrease to approximately $-11 \%$ to $-13 \%$. The lightest/lowest values, approximately $-19 \%$, occur at the first phototrophic biofilm site (yellow + green mat sites 4 and 11) across the photosynthetic fringe. Samples downchannel into the orange + green mat (sites 5, 6, 12 and 13) have values that are heavier than that of the yellow + green mat, ranging between $-13 \%$ and $-17 \%$.

\subsection{Carbon Isotope Fractionation by Thermophiles}

[19] Context for the fractionations observed for biofilms at "Bison Pool" is provided by experiments conducted with thermophilic microorganisms that use known carbon fixation 
Table 1. Analytical Results for Water, Biofilm, and Contextual Samples Collected From or Near "Bison Pool"a

\begin{tabular}{|c|c|c|c|c|c|c|c|c|c|c|c|c|}
\hline \multirow[b]{2}{*}{ Site } & \multirow[b]{2}{*}{ Sample Water } & \multirow[b]{2}{*}{$\begin{array}{l}\text { Temperature } \\
\quad\left({ }^{\circ} \mathrm{C}\right)\end{array}$} & \multirow[b]{2}{*}{$\mathrm{pH}$} & \multirow[b]{2}{*}{$\begin{array}{l}\text { Conductivity } \\
(\mu \mathrm{S})\end{array}$} & \multicolumn{4}{|c|}{ Dissolved Inorganic Carbon } & \multicolumn{4}{|c|}{ Dissolved Organic Carbon } \\
\hline & & & & & $\begin{array}{c}\mathrm{ppm} \\
\mathrm{C}\end{array}$ & $\begin{array}{c}\% \\
\text { RSD }\end{array}$ & $\begin{array}{r}\delta^{13} \mathrm{C} \\
(\% 0)\end{array}$ & $\mathrm{SD}$ & ppm C & $\begin{array}{c}\% \\
\text { RSD }\end{array}$ & $\begin{array}{r}\delta^{13} \mathrm{C} \\
(\% 0)\end{array}$ & SD \\
\hline 1 & Source & 93.3 & 7.4 & 3208 & 82.0 & 0.63 & -0.06 & 0.07 & 0.42 & 2.15 & -24.9 & 2.85 \\
\hline 2 & Outflow 1 & 79.4 & 7.7 & 2900 & 77.1 & 0.61 & 0.41 & 0.23 & 0.40 & 2.15 & -24.2 & 3.06 \\
\hline 3 & Outflow 2 & 67.5 & 7.9 & 2472 & 78.7 & 0.54 & 0.52 & 0.23 & 0.53 & 2.15 & -25.0 & 2.03 \\
\hline 4 & Outflow 3 & 65.3 & 8.0 & 2458 & 78.8 & 2.1 & 0.32 & 0.02 & 0.40 & 2.15 & -24.5 & 3.06 \\
\hline 5 & Outflow 4 & 57.1 & 8.3 & 2232 & 80.1 & 2.06 & 0.30 & 0.06 & 0.53 & 2.15 & -25.1 & 2.04 \\
\hline 6 & Outflow 5 & 58.0 & 8.2 & 2275 & 80.7 & 1.94 & 0.27 & 0.13 & 0.52 & 2.15 & -24.6 & 2.08 \\
\hline 7 & Source & 93.2 & 7.5 & 3520 & 63.6 & 1.57 & -0.20 & 0.12 & 0.80 & 2.00 & -23.2 & 0.47 \\
\hline 8 & Outflow 0.5 & 87.0 & 7.6 & 3333 & $\mathrm{nsc}$ & & nsc & & $\mathrm{nsc}$ & & nsc & \\
\hline 9 & Outflow 1 & 81.0 & 7.8 & 3188 & 63.3 & 0.51 & 0.16 & 0.06 & 1.15 & 3.78 & -21.3 & 0.15 \\
\hline 10 & Outflow 2 & 73.5 & 8.0 & 2796 & 63.0 & 0.78 & 0.13 & 0.07 & 1.05 & 3.78 & -23.0 & 0.15 \\
\hline 11 & Outflow 3 & 71.1 & 8.1 & 2860 & 61.2 & 0.76 & 0.38 & 0.13 & 0.45 & 2.00 & $(-24.2)$ & $(0.50)$ \\
\hline 12 & Outflow 4 & 65.6 & 8.2 & 2727 & 61.8 & 0.46 & 0.29 & 0.15 & 1.18 & 3.78 & -23.7 & 0.15 \\
\hline 13 & Outflow 5 & 59.9 & 8.3 & 2547 & 61.5 & 1.82 & 0.60 & 0.11 & 0.73 & 2.10 & $(-18.8)$ & $(4.00)$ \\
\hline 9 & Outflow 1 & 81.4 & 7.8 & 3164 & $\mathrm{nsc}$ & & & & $\mathrm{nsc}$ & & & \\
\hline 13 & Outflow 5 & 53.2 & 8.6 & 2372 & nsc & & & & $\mathrm{nsc}$ & & & \\
\hline Site & Sample Biofilms & $\begin{array}{l}\text { Temperature } \\
\left({ }^{\circ} \mathrm{C}\right)\end{array}$ & $\mathrm{pH}$ & $\begin{array}{c}\% \mathrm{C} \\
\text { (by dw) }\end{array}$ & $\begin{array}{c}\mathrm{SD} \% \\
\mathrm{C} \\
( \pm)\end{array}$ & $\begin{array}{r}\delta^{13} \mathrm{C} \\
(\% 0)\end{array}$ & $\begin{array}{c}\mathrm{SD} \delta^{13} \mathrm{C} \\
( \pm)\end{array}$ & $\begin{array}{c}\Delta^{13} \mathrm{C} \text { vs } \\
\text { DIC }\end{array}$ & $\begin{array}{l}\% \mathrm{~N} \\
\text { (by dw) }\end{array}$ & $\begin{array}{l}\mathrm{SD} \% \mathrm{~N} \\
( \pm)\end{array}$ & $\begin{array}{r}\delta^{15} \mathrm{~N} \\
(\% 0)\end{array}$ & $\begin{array}{c}\operatorname{SD} \delta^{15} \mathrm{~N} \\
( \pm)\end{array}$ \\
\hline 1 & White Goo & 93.3 & 7.4 & $(1.75)$ & $(0.01)$ & $(-4.96)$ & $(0.03)$ & $(-4.90)$ & $(0.143)$ & $(0.001)$ & $(2.90)$ & $(0.06)$ \\
\hline 2 & Pinkish Filaments & 79.4 & 7.7 & 11.19 & 0.43 & -12.8 & 0.6 & -13.2 & 1.10 & 0.07 & 4.05 & 0.56 \\
\hline 2 & Crab Meat & 79.4 & 7.7 & 0.80 & 0.01 & -9.76 & 1.06 & -10.2 & 0.080 & 0.001 & 4.19 & 0.36 \\
\hline 3 & Whitish Filaments & 67.5 & 7.9 & 1.84 & 0.08 & -12.6 & 0.4 & -13.1 & 0.157 & 0.006 & 6.56 & 0.89 \\
\hline 4 & Yellow-Green Mat & 65.3 & 8.0 & 4.66 & 0.11 & -19.6 & 0.2 & -19.9 & 0.656 & 0.028 & 8.54 & 0.19 \\
\hline 5 & Orange-Green Mat & 57.1 & 8.3 & 3.14 & 0.30 & -17.2 & 0.2 & -17.4 & 0.414 & 0.038 & 6.67 & 0.81 \\
\hline 6 & Orange-Green Mat & 58.0 & 8.2 & 6.75 & 0.60 & -14.7 & 0.2 & -15.0 & 0.970 & 0.083 & 3.32 & 0.08 \\
\hline 7 & Pinkish Filaments & 93.2 & 7.5 & 3.97 & 0.19 & -4.3 & 0.65 & -4.07 & 0.486 & 0.015 & 2.62 & 0.47 \\
\hline 7 & White Goo & 93.2 & 7.5 & 1.61 & 0.08 & -3.9 & 0.12 & -3.69 & 0.144 & 0.006 & 2.15 & 0.02 \\
\hline 8 & Pinkish Filaments & 87.0 & 7.6 & 12.22 & 0.30 & -4.4 & 0.31 & -4.35 & 1.73 & 0.02 & 2.31 & 0.07 \\
\hline 9 & $\begin{array}{l}\text { Pinkish-Yellow } \\
\text { Filaments }\end{array}$ & 81.0 & 7.8 & 4.95 & 0.43 & -7.1 & 0.13 & -7.28 & 0.453 & 0.034 & 4.52 & 0.12 \\
\hline 9 & Crab Meat & 81.0 & 7.8 & 1.13 & 0.03 & -4.2 & 0.10 & -4.36 & 0.103 & 0.004 & 3.97 & 0.21 \\
\hline 10 & $\begin{array}{l}\text { Pinkish-White } \\
\text { Filaments }\end{array}$ & 73.5 & 8.0 & 1.51 & 0.09 & -10.3 & 0.4 & -10.4 & 0.119 & 0.005 & 4.91 & 0.38 \\
\hline 11 & White Filaments & 71.1 & 8.1 & 1.95 & 0.12 & -11.4 & 0.7 & -11.8 & 0.166 & 0.010 & 5.29 & 0.37 \\
\hline 12 & Yellow-Green Mat & 65.6 & 8.2 & 2.34 & 0.12 & -18.5 & 0.04 & -18.8 & 0.308 & 0.013 & 8.10 & 0.03 \\
\hline 13 & Orange-Green Mat & 59.9 & 8.3 & 14.36 & 0.23 & -13.4 & 0.02 & -14.0 & 1.77 & 0.03 & 0.95 & 0.21 \\
\hline 13 & Orange-Green Mat & 59.9 & 8.3 & 11.87 & 0.55 & -16.0 & 0.2 & -16.6 & 1.44 & 0.09 & -0.71 & 0.04 \\
\hline 9 & $\begin{array}{l}\text { Pinkish Filaments } \\
\text { (Farm) }\end{array}$ & 81.4 & 7.8 & 20.27 & 1.26 & $(-3.33)$ & & -3.48 & 3.75 & 0.19 & 2.72 & 0.07 \\
\hline 9 & Pinkish Filaments & 81.4 & 7.8 & 16.67 & 0.86 & -3.17 & 0.30 & -3.33 & 2.51 & 0.15 & 3.07 & 0.06 \\
\hline 13 & Orange-Green Mat & 53.2 & 8.6 & 18.86 & 0.34 & -13.8 & 0.2 & -14.4 & 2.43 & 0.03 & -0.08 & 0.09 \\
\hline 1 & Silica Precipitate & 93.3 & 7.4 & 0.37 & 0.04 & -9.57 & 0.93 & -9.52 & 0.041 & 0.001 & 0.94 & 0.52 \\
\hline & Meadow Soil & & & 1.60 & 0.03 & -27.1 & 0.2 & & 0.089 & 0.002 & 1.90 & 0.11 \\
\hline & Extinct Vent Sinter Soil & & & 2.96 & 0.08 & -25.9 & 0.1 & & 0.170 & 0.002 & 3.19 & 0.14 \\
\hline & Sinter-derived Soil & & & 1.42 & 0.05 & -20.4 & 0.1 & & 0.156 & 0.005 & 1.48 & 0.10 \\
\hline & $\begin{array}{l}\text { Sinter soil with Org. } \\
\text { matter }\end{array}$ & & & 14.90 & 0.80 & $(-28.0)$ & & & 0.769 & 0.042 & 1.42 & 0.05 \\
\hline & Local Bison Fur & & & 46.80 & 0.25 & -24.4 & 0.1 & & 15.81 & 0.15 & 4.51 & 0.31 \\
\hline & $\begin{array}{l}\text { Insects found in } \\
\text { channel }\end{array}$ & & & 44.13 & 2.37 & -23.6 & 0.1 & & 8.02 & 0.61 & 3.11 & 0.24 \\
\hline & Bison Excrement & & & $(38.2)$ & & $(-28.6)$ & & & $(2.00)$ & & $(3.29)$ & \\
\hline & Local Grasses & & & 41.58 & 0.12 & -13.0 & 0.01 & & 2.33 & 0.03 & 0.29 & 0.30 \\
\hline & Local Sedges & & & 44.54 & 0.13 & -26.7 & 0.04 & & 1.90 & 0.05 & -1.35 & 0.35 \\
\hline
\end{tabular}

${ }^{\mathrm{a}}$ If nsc, no sample collected; stl, signal too low to determine. Samples in parenthesis are considered semiquantitative. Values in bold are fractionations calculated from DIC values of samples collected from the same site but a different day. Water dissolved inorganic carbon (DIC) and dissolved organic carbon (DOC) are reported as parts per million carbon; $\mathrm{C}$ and $\mathrm{N}$ mass for biofilms are reported as percentage of dry weight of sample.

pathways from previous work. Several pioneering efforts of this type are summarized in Table 2 and taken together allow predictions of the most likely carbon fixation pathways responsible for the observed isotopic data. Figure 6 shows plots of fractionations reported in the literature organized by carbon fixation pathway and reveal differences among the fractionations produced by autotrophic organisms. Phototrophic microorganisms using the reductive pentose phos- phate cycle (PEP, Figure 6a) induce a biomass $\Delta^{13} \mathrm{C}$ fractionation of $\sim-17 \%$ at $70^{\circ} \mathrm{C}$, and up to $-27.5 \%$, at temperatures $<70^{\circ} \mathrm{C}$, in laboratory tests. Chemotrophic microorganisms that use the reductive tricarboxylic acid cycle (TCA, Figure 6b) produce a narrow range of $\Delta^{13} \mathrm{C}$ fractionations in the laboratory starting at $<-5 \%$ at temperatures above $95^{\circ} \mathrm{C}$ and increasing to $-10 \%$ as temperature decreases to $67^{\circ} \mathrm{C}$. In contrast, chemotrophic microorganisms that use 

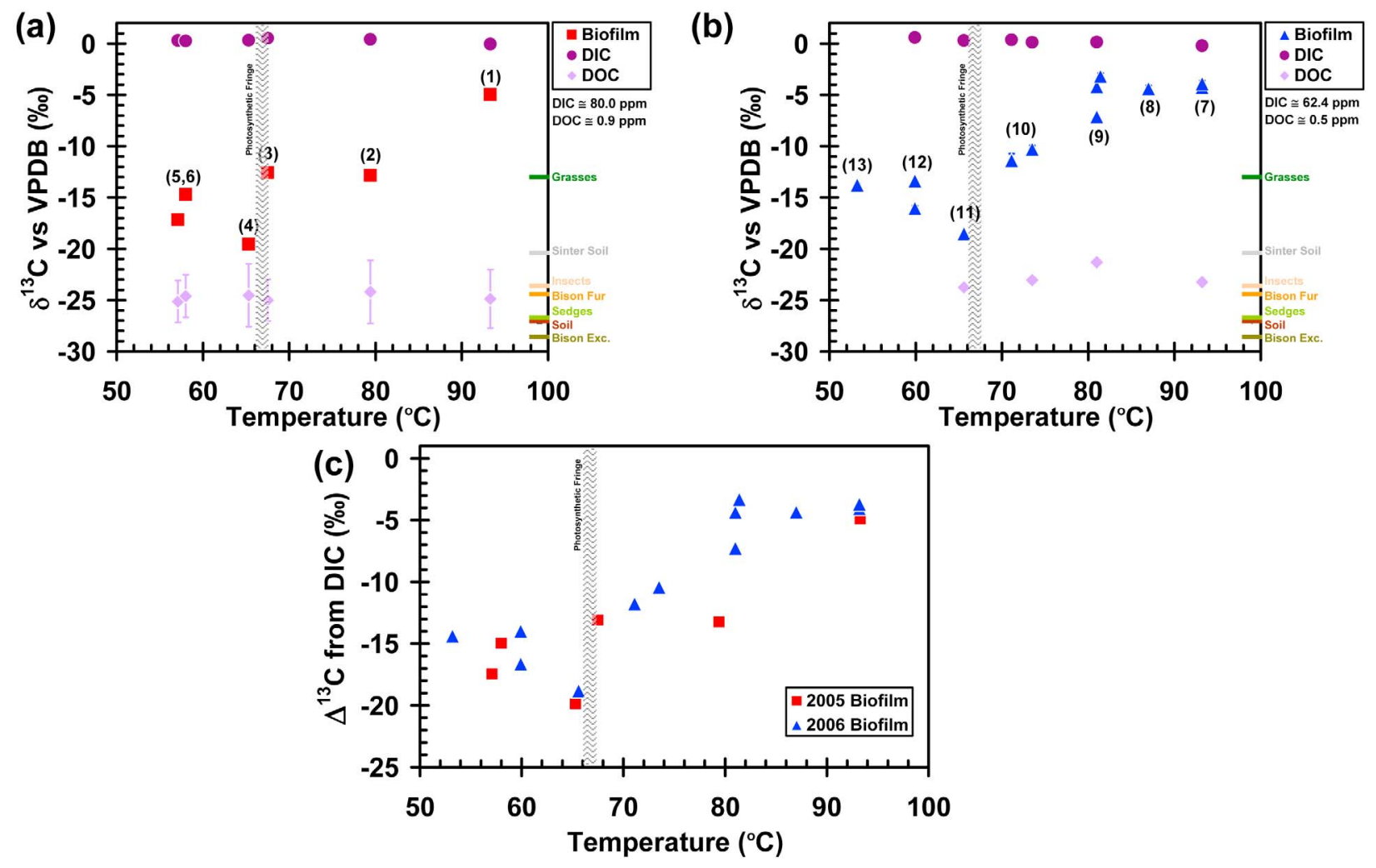

Figure 5. Carbon stable isotope values and isotopic fractionations in biofilms from "Bison Pool" plotted against temperature, as reported in Table 2. (a) Carbon isotope values for dissolved inorganic carbon (DIC), dissolved organic carbon (DOC), and biofilms collected in 2005 with contextual samples plotted along the right side. Contextual samples are plotted on the right axis and include plants growing alongside the outflow channel (Grasses, Sedges), sinter-derived soil (Sinter Soil), insects found in the outflow channel (Insects), bison fur collected near "Bison Pool" (Bison Fur), meadow soil collected form site 15 (Soil), and bison excrement collected from near "Bison Pool" (Bison Exc.). Numbers next to biofilm points represent equivalent metagenomic sample identification. The photosynthetic fringe is represented by the shaded bar at approximately $67^{\circ} \mathrm{C}$. Error bars are present for all analyses but are often within the data point symbol. (b) As in Figure 5a, only for DIC, DOC, and biofilm samples collected in 2006. (c) Biofilm fractionation from DIC.

the acetyl coenzyme A pathway (ACP, Figure 6c) produce a large spread of $\Delta^{13} \mathrm{C}$ values $(-5 \%$ to $-28 \%$ ) over a wide temperature range (from 45 to $100^{\circ} \mathrm{C}$ ) in laboratory culture. Microorganisms that use the 3-hydroxypropionate pathway (3HP, Figure 6d) create biomass in culture with $\Delta^{13} \mathrm{C}$ fractionations that are less than $-3 \%$ at or above $65^{\circ} \mathrm{C}$ but significantly greater $\left(-12 \%\right.$ to $-14 \%$ ) below $65^{\circ} \mathrm{C}$. Note that microorganisms grown at the higher temperatures with the lowest fractionations were chemotrophic, while the cooler temperature, higher fractionating microorganisms were phototrophic.

[20] Using literature values as a guideline, we can predict which carbon fixation pathways are likely to be in use at the various sites of "Bison Pool" biofilms, based on $\Delta^{13} \mathrm{C}$ of our samples. A comparison of observed biofilm fractionations with those of cultured hydrothermal microorganisms with known $\mathrm{C}$ fixation pathways is shown in Figure 7. The regions where there is overlap between the observed biofilm fractionations (hachured areas) and those of literature values for the known $\mathrm{C}$ fixation pathways are assumed to be the best fit. As an example of using this assumption, data from site 1 can be interpreted to indicate that TCA and possibly
$\mathrm{ACP}$ are the most likely $\mathrm{C}$ fixation pathways present. An analogous approach leads to predictions of TCA and ACP for sites 2 and 3, PEP and ACP for site 4, and ACP for site 5. However, combinations of signals from two different C fixation pathways produced by different microorganisms present in the same biofilm may also produce an overall biofilm signal that would not necessarily overlap with the actual pathways represented by monocultures. Possible examples of this include the combination of $3 \mathrm{HP}$ and $\mathrm{ACP}$ at site 1, and PEP and 3HP at site 5. Although this comparison is helpful for predicting the carbon fixing pathways that are likely to be present in a biofilm, it does not indicate which of the pathways are actually operational in any biofilm sample. For these reasons, we turn to metagenomic analyses of the samples collected in 2005 to identify the presence of genes involved in the various carbon fixation pathways.

\subsection{Metagenomic Results for Carbon Fixation Pathways}

[21] Metagenomic analysis was conducted by JGI for biofilms from 2005 sample sites 1-5. Diagnostic genes used 
Table 2. Isotopic Fractionations of Cultured Hydrothermal Microorganisms as Reported in the Literature for the Four Known Carbon Fixation Pathways ${ }^{\mathrm{a}}$

\begin{tabular}{|c|c|c|c|c|c|c|c|c|}
\hline Organism & $\begin{array}{l}\text { C Fixation } \\
\text { Pathway }\end{array}$ & $\begin{array}{c}\text { Temperature } \\
\left({ }^{\circ} \mathrm{C}\right)\end{array}$ & $\begin{array}{c}\delta^{13} \mathrm{C} \text { of } \\
\mathrm{CO}_{2(\mathrm{aq})} \\
(\% 0)\end{array}$ & $\begin{array}{c}\delta^{13} \mathrm{C} \\
\text { of DIC } \\
(\%)\end{array}$ & $\begin{array}{c}\delta^{13} \mathrm{C} \text { of } \\
\text { Biomass } \\
(\%)\end{array}$ & $\begin{array}{l}\Delta^{13} \mathrm{C}^{\mathrm{b}} \\
(\% \mathrm{o})\end{array}$ & $\mathrm{pH}^{\mathrm{c}}$ & Literature Source \\
\hline Synechococcus lividus $\mathrm{OH}-68 \mathrm{~s}$ & PEP & 70.0 & & & & -16.8 & & Pardue et al. [1976] \\
\hline Synechococcus sp. & PEP & 57.0 & & & & -22.5 & & $\begin{array}{l}\text { Mizutani and Wada } \\
\text { [1982] }\end{array}$ \\
\hline Biomass (mostly Chromatium tepidum) & PEP & 52.0 & & & -28.7 & -26.6 & 6.7 & Madigan et al. [1989] \\
\hline Chromatium tepidum & PEP & 50.0 & & & & -27.5 & & Madigan et al. [1989] \\
\hline Synechococcus lividus $\mathrm{OH}-53$ & PEP & 47.0 & & & & -20.0 & & Pardue et al. [1976] \\
\hline Pyrolobus fumarii & $\mathrm{TCA}^{\mathrm{d}}$ & 105.0 & -26.6 & -26.5 & -30.3 & -3.8 & 5.5 & House et al. [2003] \\
\hline Psyroditium occultum & $\mathrm{TCA}^{\mathrm{d}}$ & 102.0 & -26.1 & -26.0 & -28.4 & -2.4 & 5.5 & House et al. [2003] \\
\hline Pyrobaculum aerophilum & TCA & 100.0 & -23.3 & -21.9 & -26.2 & -4.3 & 7.0 & House et al. [2003] \\
\hline Aquifex aeolicus & TCA & 85.0 & -24.4 & -21.9 & -29.6 & -7.7 & 7.0 & House et al. [2003] \\
\hline Thermoproteus neutrophilus & TCA & 85.0 & -25.7 & -24.2 & -27.7 & -3.5 & 6.0 & House et al. [2003] \\
\hline $\begin{array}{l}\text { Thermocrinis ruber OC } 1 / 4 \\
\text { (DSM 12173) }\end{array}$ & TCA & 80.0 & -27.4 & $-25.5(0.9)$ & $-30.7(0.1)$ & -5.2 & 6.5 & Jahnke et al. [2001] \\
\hline Persephonella marina & TCA & 70.0 & & -30.5 & -39.9 & -9.4 & & Zhang et al. [2002] \\
\hline Persephonella marina & TCA & 70.0 & & -35.1 & -45.6 & -10.5 & & Zhang et al. [2002] \\
\hline Hydrogenobacter thermophilus & TCA & 70.0 & -25.4 & -21.9 & -30.7 & -8.8 & 6.9 & House et al. [2003] \\
\hline Methanopyrus kandleri & ACP & 100.0 & -25.7 & -24.4 & -44.1 & -19.7 & 6.5 & House et al. [2003] \\
\hline Methanopyrus kandleri & $\mathrm{ACP}$ & 100.0 & -25.5 & -24.3 & -37.4 & -13.1 & 6.4 & House et al. [2003] \\
\hline Thermoproteus neutrophilus & ACP & 85.0 & & -47.6 & -55.8 & -8.2 & & Preuss et al. [1989] \\
\hline Archaeoglobus fulgidus & $\mathrm{ACP}$ & 85.0 & -25.4 & -23.5 & -28.1 & -4.6 & 6.3 & House et al. [2003] \\
\hline Archaeoglobus fulgidus & ACP & 85.0 & -24.7 & -22.8 & -30.4 & -7.6 & 6.3 & House et al. [2003] \\
\hline Archaeoglobus lithotrophicus & $\mathrm{ACP}$ & 85.0 & -25.4 & -23.3 & -33.2 & -9.9 & 6.5 & House et al. [2003] \\
\hline Ferroglobus placidus & ACP & 85.0 & -24.8 & -22.4 & -28.3 & -5.9 & 7.0 & House et al. [2003] \\
\hline Methanococcus igneous & ACP & 85.0 & -25.1 & -23.2 & -43.8 & -20.6 & 6.3 & House et al. [2003] \\
\hline Methanococcus jannaschii & ACP & 85.0 & -25.5 & -23.5 & -31.3 & -7.8 & 6.3 & House et al. [2003] \\
\hline Methanothermus fervidus & $\mathrm{ACP}$ & 85.0 & -26.0 & -24.0 & -38.1 & -14.1 & 6.5 & House et al. [2003] \\
\hline Methanothermus jannaschii & $\mathrm{ACP}$ & 85.0 & -28.0 & -26.0 & -43.6 & -17.6 & 6.3 & House et al. [2003] \\
\hline Methanothermus jannaschii & ACP & 85.0 & -26.7 & -24.8 & -36.7 & -11.9 & 6.3 & House et al. [2003] \\
\hline Methanothermus jannaschii & $\mathrm{ACP}$ & 85.0 & -26.9 & -25.0 & -39.6 & -14.6 & 6.3 & House et al. [2003] \\
\hline Methanococcus thermolithotrophicus & ACP & 70.0 & -26.5 & -23.7 & -49.4 & -25.7 & 6.3 & House et al. [2003] \\
\hline Methanobacterium thermoauto & $\mathrm{ACP}$ & 65.0 & -26.3 & -23.2 & -40.2 & -17.0 & 6.5 & House et al. [2003] \\
\hline Methanococcus thermolithotrophicus & ACP & 65.0 & -27.0 & -23.9 & -47.6 & -23.7 & 6.3 & House et al. [2003] \\
\hline Methanococcus thermolithotrophicus & ACP & 65.0 & -26.4 & -23.3 & -50.2 & -26.9 & 6.3 & House et al. [2003] \\
\hline Methanococcus thermolithotrophicus & $\mathrm{ACP}$ & 65.0 & -26.3 & -23.2 & -51.2 & -28.0 & 6.3 & House et al. [2003] \\
\hline Methanococcus thermolithotrophicus & $\mathrm{ACP}$ & 65.0 & -26.5 & -23.4 & -49.4 & -26.0 & 6.3 & House et al. [2003] \\
\hline Methanococcus thermolithotrophicus & $\mathrm{ACP}$ & 65.0 & -24.6 & -21.5 & -49.1 & -27.6 & 6.3 & House et al. [2003] \\
\hline Methanococcus thermolithotrophicus & $\mathrm{ACP}$ & 65.0 & -26.2 & -23.1 & -34.4 & -11.3 & 6.3 & House et al. [2003] \\
\hline Methanococcus thermolithotrophicus & $\mathrm{ACP}$ & 60.0 & -26.1 & -22.7 & -44.9 & -22.2 & 6.3 & House et al. [2003] \\
\hline Methanococcus thermolithotrophicus & ACP & 51.0 & -26.0 & -22.1 & -38.9 & -16.8 & 6.3 & House et al. [2003] \\
\hline Methanococcus thermolithotrophicus & $\mathrm{ACP}$ & 45.0 & -27.9 & -23.7 & -46.4 & -22.7 & 6.3 & House et al. [2003] \\
\hline Methanococcus thermolithotrophicus & ACP & 45.0 & -26.2 & -21.9 & -39.1 & -17.2 & 6.3 & House et al. [2003] \\
\hline Methanococcus thermolithotrophicus & $\mathrm{ACP}$ & 45.0 & -26.1 & -21.9 & -30.8 & -8.9 & 6.3 & House et al. [2003] \\
\hline Methanococcus thermolithotrophicus & ACP & 45.0 & -27.8 & -24.7 & -46.7 & -22.0 & 6.3 & House et al. [2003] \\
\hline Sulfolobus solfataricus RON 12 III & $3 \mathrm{HP}$ & 85.0 & -25.9 & -26.8 & -26.1 & 0.7 & 2.0 & House et al. [2003] \\
\hline Metallosphaera sedula $\mathrm{TH} 2$ & $3 \mathrm{HP}$ & 65.0 & $-43.1(0.4)$ & -38.3 & $-40.2(0.2)$ & -1.9 & 2.0 & $\begin{array}{l}\text { van der Meer et al. } \\
{[2000 \mathrm{~b}]}\end{array}$ \\
\hline Acidianus brierleyi & 3HP & 65.0 & -24.4 & -25.3 & -27.9 & -2.6 & 2.0 & House et al. [2003] \\
\hline Metallosphaera sedula & $3 \mathrm{HP}$ & 65.0 & -25.9 & -26.9 & -28.9 & -2.0 & 2.0 & House et al. [2003] \\
\hline $\begin{array}{l}\text { Chloroflexus aurantiacus OK-70fl } \\
\text { (DSM 636) }\end{array}$ & $3 \mathrm{HP}$ & 55.0 & $-41.6(0.09)$ & -35.9 & $-48.9(0.04)$ & -13.0 & 8.3 & $\begin{array}{l}\text { van der Meer et al. } \\
{[2000 \mathrm{a}]}\end{array}$ \\
\hline Chloroflexus aurantiacus & $3 \mathrm{HP}$ & 55.0 & & & & -13.7 & & House et al. [2003] \\
\hline
\end{tabular}

${ }^{a}$ Reported values include the microorganism studied (Organism), the carbon fixation pathway used by the microorganism (C Fixation Pathway) for the pentose phosphate cycle (PEP), the reverse tricarboxylic acid cycle (TCA), the acetyl-coenzyme A pathway (ACP), and the 3-hydroxypropionate pathway (3HP), the temperature at which the experiment was carried out (Temperature), the $\delta^{13} \mathrm{C}$ of the aqueous $\mathrm{CO}_{2}\left(\mathrm{CO} 2_{(\mathrm{aq})}\right)$, DIC, and biomass, the fractionation observed $\left(\Delta^{13} \mathrm{C}\right)$ from the dissolved inorgarnic carbon source $\left(\delta^{13} \mathrm{C}\right.$ of DIC) to the biomass $\left(\delta^{13} \mathrm{C}\right.$ of Biomass), the $\mathrm{pH}$, and the literature source for the data. Numbers in parentheses denote standard deviations. Numbers in italic indicate that the value is an approximation. Blank when the value was not reported.

${ }^{\mathrm{b}}$ Values are calculated from $\delta^{13} \mathrm{C}$ DIC values.

${ }^{\mathrm{c}}$ Value from House et al. [2003] were taken of media at $25^{\circ} \mathrm{C}$.

${ }^{\mathrm{d}}$ Assumed carbon fixation pathway.

to determine the presence of specific carbon fixation pathways are described in detail by Raymond [2005]. Key enzymes used were ribulose-1,5-biphosphate carboxylase/ oxygenase (RuBisCO) for PEP, fumerate reductase (frd), ATP citrate lyase (acl), and 2-oxoglutarate:ferredoxin oxidore- ductase (OGOR) for TCA, malonyl-coenzyme A reductase (mcr) and propionyl-coenzyme A synthase (pcs) for 3HP, and carbon monoxide dehydrogenase (CODH) and acetylcoenzyme A synthase (acs) for ACP. 

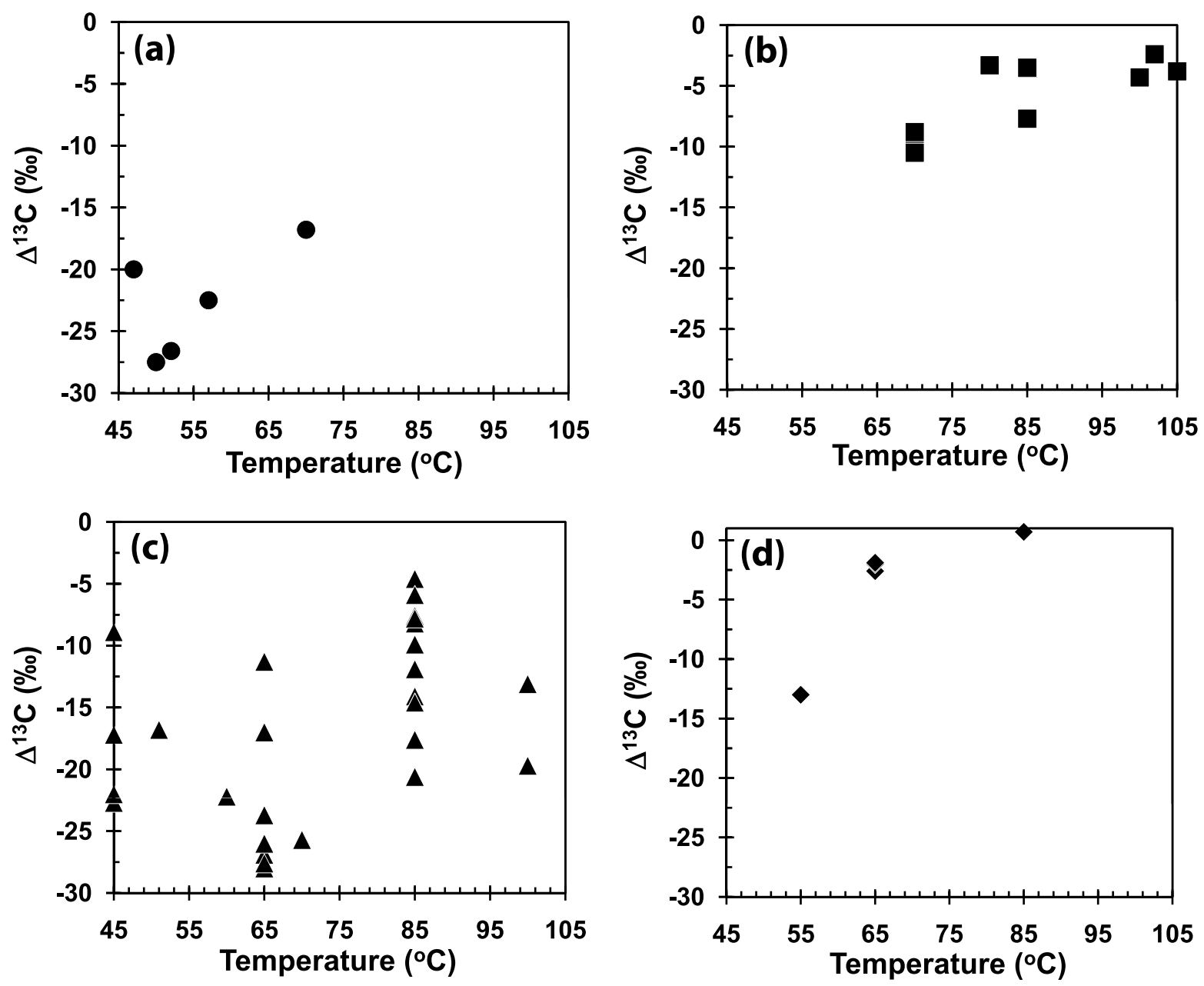

Figure 6. Fractionations reported in Table 2 for the four major carbon fixation pathways: (a) pentose phosphate cycle (PEP), (b) reverse tricarboxylic acid cycle (TCA), (c) acetyl coenzyme A pathway (ACP), and (d) 3-hydroxypropionate pathway (3HP).

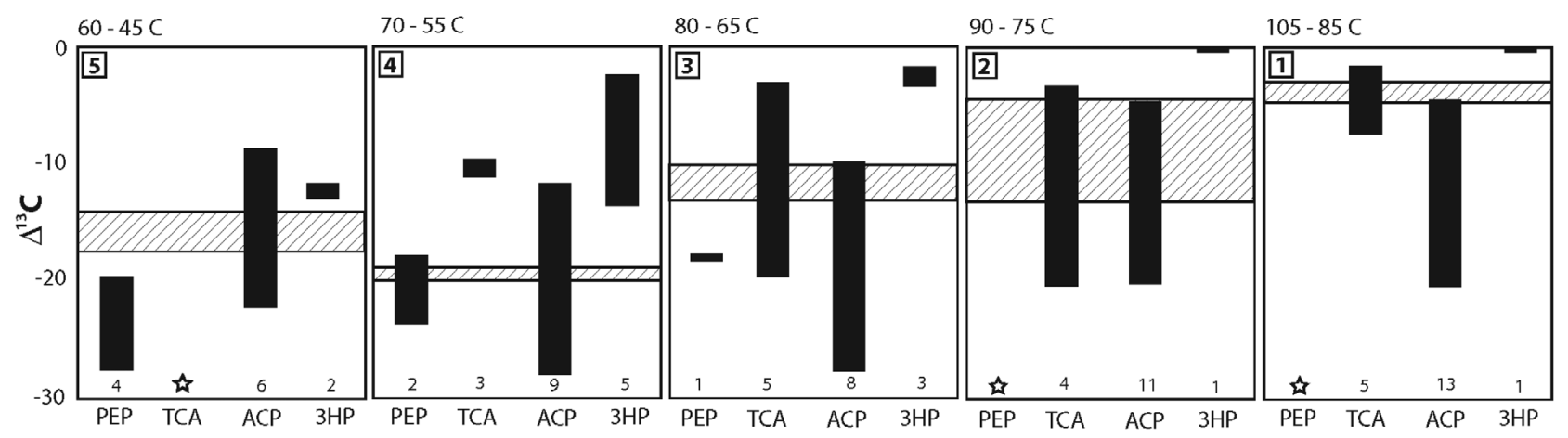

Figure 7. Comparison of observed biofilm $\Delta^{13} \mathrm{C}$ fractionations to values from the literature of cultured hydrothermal microorganisms, grouped by temperatures associated with sites $1-5$. Numbers indicate the total number of data points reported in the literature for each pathway at the temperature range shown. Black bars represent the range of values for each pathway with data available. Hachured areas show ranges of values for "Bison Pool" biofilms. Stars indicate a lack of literature data available for that temperature range. PEP, pentose phosphate cycle; TCA, reverse tricarboxylic acid cycle; ACP, acetyl coenzyme A pathway; 3HP, 3-hydroxypropionate pathway. 


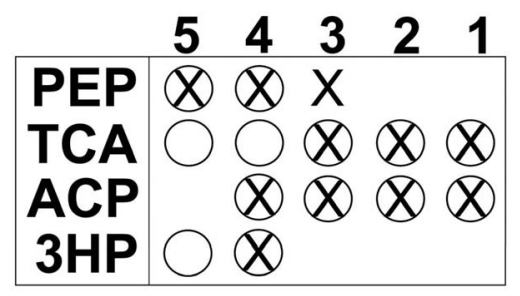

Figure 8. Overall occurrence of autotrophic carbon fixation pathways in "Bison Pool" biofilms based on metagenome analysis. The cross represents definitive enzymes indicative of the given carbon fixation pathway, and the circle corresponds to the presence of microorganisms related to known users of the carbon fixation pathways indicated based on 16S rRNA gene data. Numbers correspond to 2005 sample sites. Abbreviations: PEP, pentose phosphate cycle; TCA, reverse tricarboxylic acid cycle; ACP, acetyl coenzyme A pathway; 3HP, 3-hydroxypropionate pathway.

[22] Initial results from searches of key enzymes involved with the four main carbon fixation pathways coupled with $16 \mathrm{~S}$ rRNA gene analysis are summed in Figure 8. The qualitative carbon fixation enzyme search results indicate whether genes for enzymes involved in each carbon fixation pathway are present at each site but do not give quantitative results for the overall abundance of the genes. The 16S rRNA gene analysis provide phylogenetic evidence for the presence of related species that are known to utilize a given carbon fixation pathway, based on laboratory experimentation. The metagenomes of sites 1 and 2 both yielded genes involved in the TCA and ACP pathways, but not for $3 \mathrm{HP}$ or PEP. Genes for TCA, ACP, and PEP are present at site 3, but not 3HP. Biofilms at site 4 contain genes for ACP, 3HP, and PEP, but not TCA. The only pathway revealed by genetic analysis from site 5 is PEP, and no gene sequences indicative of TCA, $\mathrm{ACP}$, or $3 \mathrm{HP}$ were found.

\subsection{Discussion of Carbon Uptake Pathways}

[23] Combining carbon isotopic fractionation data for "Bison Pool" biofilms, together with measured $\Delta^{13} \mathrm{C}$ fractionation values for thermophilic autotrophic microorganisms that use known carbon fixation pathways, and metagenomic analysis for five biofilm samples makes it possible to identify relative changes in autotrophic $\mathrm{CO}_{2}$ uptake pathways throughout this hot spring ecosystem. The results show dramatic shifts in how $\mathrm{CO}_{2}$ uptake occurs between physically associated microbial communities that are sometimes less than a meter apart.

[24] At site 1, occupied by biofilms living almost continuously in boiling water, fractionation by autotrophic organisms in the biofilm drives the stable carbon isotope values down by $-5 \%$, and the biofilm yields genetic evidence of the TCA and ACP cycles. Evidence in the literature for small fractionations by microorganisms utilizing TCA and larger fractionations by organisms using ACP at similar temperatures (Figure 6) leads to the prediction that TCA is dominant over ACP for biofilms at the source of "Bison Pool," although activity measurements would be needed to confirm this. Hyperthermophiles known to use the TCA pathway occur among the phylum Aquificae [Hugler et al., 2007], including the species Hydrogenobacter thermophilus [Shiba et al., 1985] and Aquifex pyrophilus [Beh et al., 1993]. Additionally, Thermocrinis species, also members of the Aquificae that use the TCA pathway, are commonly found by both culturing and culture-independent methods in alkaline hot springs throughout Yellowstone, including "Bison Pool" [Huber et al., 1998; Jahnke et al., 2001; Reysenbach and Cady, 2001; Blank et al., 2002; MeyerDombard et al., 2005; Robertson et al., 2005; Hall et al., 2008; Takacs-Vesbach et al., 2008]. 16S rRNA gene data from "Bison Pool," summarized in Table 3, indicate that several related members of this phylum are present among the hyperthermophilic communities at "Bison Pool" and are in one of two dominant phyla present at site 1 . The predominance of Aquificae at site 1 coupled with the carbon fractionation observed at temperatures above $\sim 82^{\circ} \mathrm{C}$ provide evidence that the TCA pathway is a predominant pathway for $\mathrm{C}$ fixation in the highest temperature biofilms.

[25] Chemoautotrophs in the biofilms at both sites 2 and 3 fractionate the stable isotopes of carbon by approximately $-13 \%$. Both sites contain evidence for genes encoding enzymes putatively involved in the TCA and ACP pathways; however, the ACP pathway in particular is difficult to infer from metagenomic data because many of the key enzymes are shared with other metabolic pathways and are thus not diagnostic for ACP. Hyperthermophiles and thermophiles that use the ACP pathway include methanogenic Euryarchaeota and a number of Gram-positive bacteria in the phylum Firmicutes, class Clostridia. 16S rRNA gene data from "Bison Pool" suggest a very small fraction of methanogens in the source biofilms and the photosynthetic mats (phylum Euryarchaeota, class Methanomicrobia, sites 1 and 5), though not in the other chemosynthetic or phototrophic communities (Table 3). 16S rRNA gene sequences that are most similar to Clostridia are present in sites 2, 3, and 4 but have not been identified in the chemosynthetic community from site 1 . These observations indicate that the source of ACP genes at site 1 may be attributable to Euryarchaeota, and sites 2-4 to

Table 3. Occurrence of Phyla Based on 16S rRNA Analysis ${ }^{\mathrm{a}}$

\begin{tabular}{|c|c|c|c|c|c|}
\hline \multirow[b]{2}{*}{ Phyla } & \multicolumn{5}{|c|}{ Sites } \\
\hline & 1 & 2 & 3 & 4 & 5 \\
\hline Crenarchaeota & $\mathrm{X}$ & $X$ & $\mathrm{X}$ & N/A & $\mathrm{X}$ \\
\hline Euryarchaeota & $\mathrm{X}$ & & & N/A & $\mathrm{X}$ \\
\hline Actinobacteria & & & & & $\mathrm{X}$ \\
\hline Aquificae & $\mathrm{X}$ & $\mathrm{X}$ & $\mathrm{X}$ & $\mathrm{X}$ & $\mathrm{X}$ \\
\hline Bacteriodetes & & & $\mathrm{X}$ & $\mathrm{X}$ & $\mathrm{X}$ \\
\hline Chlorobi & & & & $\mathrm{X}$ & $\mathrm{X}$ \\
\hline Chloroflexi & & & & $\mathrm{X}$ & $\mathrm{X}$ \\
\hline Cyanobacteria & & & & $\mathrm{X}$ & $\mathrm{X}$ \\
\hline Deinococcus-Thermus & $\mathrm{X}$ & $\mathrm{X}$ & $\mathrm{X}$ & $\mathrm{X}$ & $\mathrm{X}$ \\
\hline Firmicutes & & $\mathrm{X}$ & $\mathrm{X}$ & $\mathrm{X}$ & \\
\hline OP10 & & & & & $\mathrm{X}$ \\
\hline OP11 & & & & $\mathrm{X}$ & $\mathrm{X}$ \\
\hline Proteobacteria & $\mathrm{X}$ & $\mathrm{X}$ & $\mathrm{X}$ & $\mathrm{X}$ & $\mathrm{X}$ \\
\hline Alpha & & $\mathrm{X}$ & & $\mathrm{X}$ & $\mathrm{X}$ \\
\hline Beta & $\mathrm{X}$ & $\mathrm{X}$ & & & \\
\hline Gamma & & $\mathrm{X}$ & $\mathrm{X}$ & $\mathrm{X}$ & $\mathrm{X}$ \\
\hline Thermomicrobia & & $\mathrm{X}$ & $\mathrm{X}$ & $\mathrm{X}$ & \\
\hline Thermotogae & & & & & $\mathrm{X}$ \\
\hline
\end{tabular}

a" $\mathrm{X}$ " indicates the presence of microorganisms in the phylum. Archael 16S rRNA gene PCR was unsuccessful at site 4. 


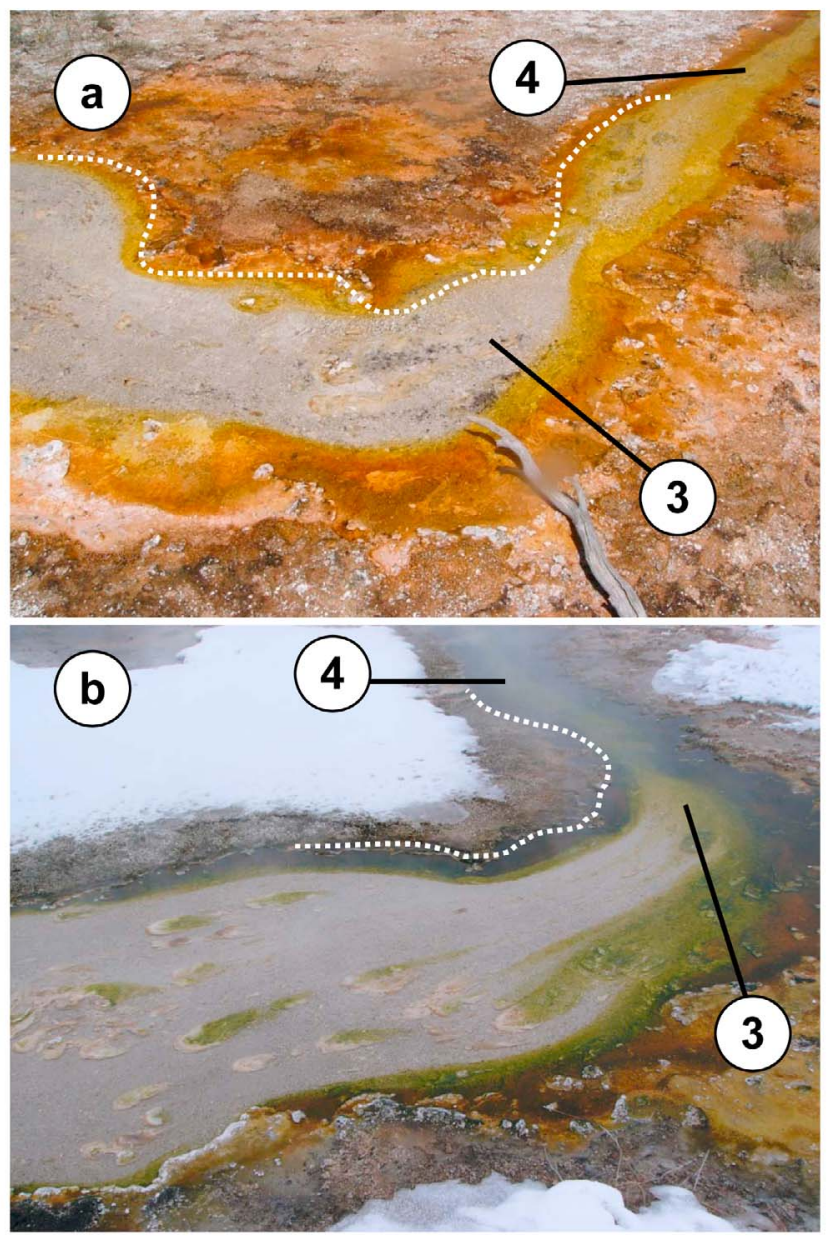

Figure 9. Comparison of "Bison Pool" outflow sample location sites 3 and 4 . The white dotted lines mark the same locations in both images for comparison. (a) Sample sites as they looked in the summer of 2005. Note clear photosynthetic fringe present between sample sites 3 and 4. (b) Sample sites as they looked in January of 2008. Note the migration of the photosynthetic fringe above site 3 .

Firmicutes and that the importance of ACP as the carbon fixation source for the biofilms at sites 2 and 3 may be attributable to an increase in Firmicutes or other ACP-using chemoautotrophs.

[26] Site 3 is unique in the presence of genes indicative of PEP (attributed to photoautotrophic Cyanobacteria) in spite of the apparent lack of photosynthetic pigments at the site. Care was taken to collect samples from biofilms living at locations on the high-temperature side of the photosynthetic fringe. Observations made of "Bison Pool" during January of 2008 may help to explain the presence of a phototrophic-type carbon fixation pathway in what was assumed to be a strictly chemotrophic zone. Figure 9 contains images of site 3 as it appeared in the summer of 2005 at the time of sample collection and again in January of 2008. Drastically colder ambient temperatures during the winter result in a cooling effect that decreases the temperature of the water at site 3 enough for the photosynthetic fringe to migrate up channel toward the hot spring source. The cooling effect is greatly diminished in the summer so that the photosynthetic fringe observed during summer field seasons is maintained from year to year in spite of the annual encroachment of phototrophs well into the apparently strictly chemotrophic zone during winter months. The presence of PEP genes at site 3 is taken to be a signature of this seasonal encroachment, even though phototrophs may not be active at the time of summer sampling, and the presence of Cyanobacteria was not shown in 16S rRNA gene data (Table 3). This suggests that sampling of biofilms at different times of the year may reveal the dynamic interplay of gene expression and carbon isotopic signals for individual sites.

[27] Autotrophs in the phototrophic biofilm at site 4 fractionate carbon by $-20 \%$ and contain genes indicative of the presence of ACP, 3HP, and PEP. There is considerable spread in the literature values for carbon fractionation via these pathways in the temperature range appropriate to this sample (see Figure 6). As a result, it is unclear how to identify whether any one fixation pathway might dominate the biofilm community. Currently available isotopic data suggest that ACP and PEP may be largely responsible for the carbon isotopic composition, but literature data for 3HP are sparse. These findings are consistent with $16 \mathrm{~S}$ rRNA gene data, which suggest site 4 is dominated by thermophilic Cyanobacteria using PEP ( $>60 \%$ of sequenced clones) and that $3 \mathrm{HP}$-utilizing Chloroflexi are much less abundant as compared to site 5 . Phototrophic mat communities should be excellent targets for efforts to further quantify the numbers of genes present from these three pathways, as well as efforts to observe the direct expression of those genes.

[28] The carbon isotopic fractionation for the site 5 phototrophic biofilm (-17.4\%o) shows a close match with literature data if PEP is the primary carbon fixation pathway present. This is supported by the metagenomic data that show the presence of PEP genes at site 5. 16S rRNA gene data show considerable phylum level variation at site 5 , including strains of Cyanobacteria, Proteobacteria, Chlorobi, Chloroflexi, Aquificae, and Crenarchaeota, among others (Table 3). The lack of other $\mathrm{C}$ fixation genes at site 5 , however, shows that the diverse PEP-utilizing Cyanobacteria are the key fixers of inorganic carbon in the lower temperature phototrophic mats.

\section{Interpretation of Nitrogen Isotopic Data}

[29] Biofilm and contextual $\delta^{15} \mathrm{~N}$ values from Table 1 are shown in Figure 10 for 2005 (Figure 10a) and 2006 (Figure 10b). As in the case of contextual data for carbon shown in Figure 5, nitrogen isotopic data from contextual samples are plotted along the right vertical axes of the plots in Figure 10. With decreasing temperature, nitrogen isotope values for biofilms from 2005 (Figure 10a) exhibit an initial increase from the source $(2.9 \%$ ) to a maximum of $8.5 \%$ at site 4 , then decrease at sites 5 and 6 . This trend is even more pronounced in the 2006 biofilm data shown in Figure 10b, where the increase from sites 7 to 11 reflects the trend observed from sites 1 to 4 in Figure 10a, followed by a decrease to nearly zero for biofilms collected from site 13 . It should be noted that values of $\delta^{15} \mathrm{~N}$ that approach zero are equivalent to the isotopic composition of atmospheric $\mathrm{N}_{2}$. 

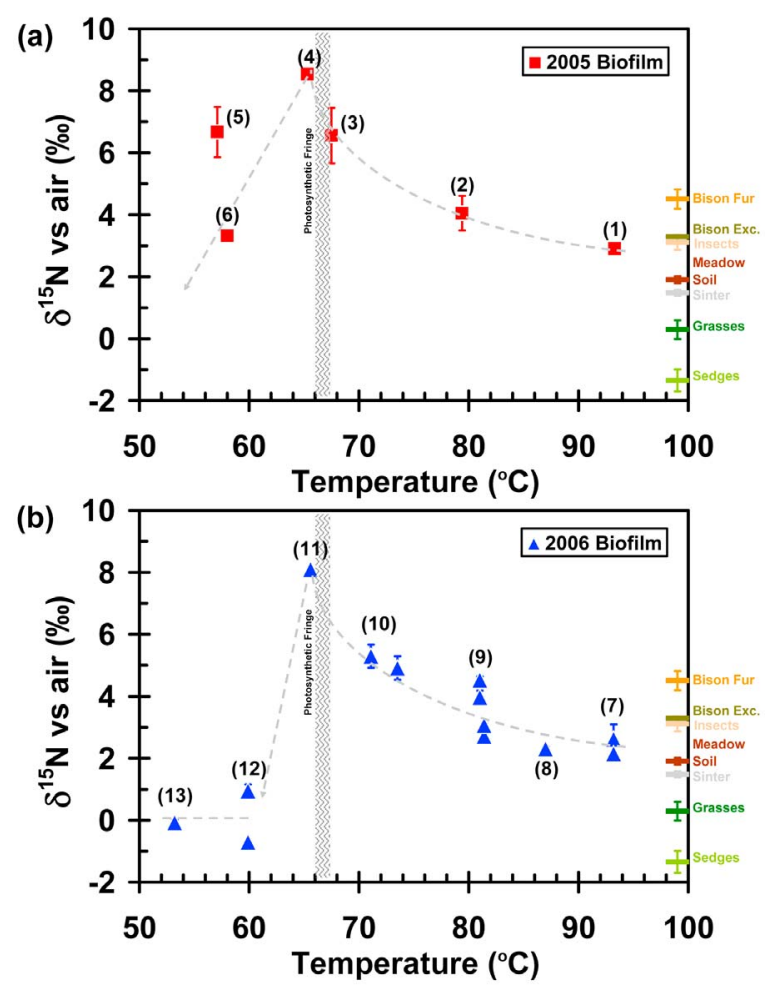

Figure 10. Nitrogen stable isotope values and isotopic fractionations in biofilms from "Bison Pool" plotted against temperature, as reported in Table 2. (a) Nitrogen isotope values for biofilms collected in 2005 with contextual samples plotted along the right side. Numbers represent sample locations and correlate to metagenomic analysis. Contextual samples are plotted on the right axis and include plants growing alongside the outflow channel (grasses, sedges), sinter-derived soil (sinter soil), insects found in the outflow channel (insects), bison fur collected near "Bison Pool" (Bison Fur), meadow soil (Soil), and bison excrement collected from near "Bison Pool" (Bison Exc.). Numbers next to biofilm points represent equivalent metagenomic sample identification. The photosynthetic fringe is represented by the shaded bar at approximately $67^{\circ} \mathrm{C}$. (b) As in Figure 10a, only for biofilm samples collected in 2006 .

[30] There are several possible sources of nitrogen for the biofilms, including particulates from aeolian deposition and inorganic solutes. Among the contextual $\delta^{15} \mathrm{~N}$ values those of meadow soil, bison excrement, and insects all fall within approximately $1 \%$ of the biofilm values from the "Bison Pool" source (samples 1 and 7). This similarity permits the interpretation that external biological and soil nitrogen is available to the biofilms at the hot spring source. Nitrate at "Bison Pool" is at low concentrations, highest at the source $\left(5 \times 10^{-5}\right.$ molal $)$ and decreasing down the outflow channel [Havig, 2009]. Nitrite measurements are typically indistinguishable from field blank values, and total ammonia is below detection limits throughout the hot spring system. Although we have not measured the dissolved organic nitrogen, we suspect that concentrations are quite low given the scarcity of dissolved organic carbon.
[31] The low concentrations of nitrogen sources suggest that nitrogen is a limiting nutrient for the biofilms. This may help to explain the initial increase in $\delta^{15} \mathrm{~N}$ of biofilms down the outflow channel. Fractionation of nitrogen isotopes upon the uptake of nitrate is assumed to be negligible [Needoba et al., 2004]. However, in a nitrogen-limited system that depends on nitrate, microbes will take up any nitrate available but preferentially use ${ }^{14} \mathrm{NO}_{3}^{-}$from the pool of intracellular nitrate. As a result, nitrate that is passively lost from the microbes will be enriched in ${ }^{15} \mathrm{NO}_{3}^{-}$. This effect has been demonstrated in laboratory experiments with phytoplankton using limited nitrate as a sole nitrogen source [Waser et al., 1998; Needoba et al., 2004] and in natural systems [De Brabandere et al., 2007]. In a flowing N-limited system, the ${ }^{15} \mathrm{~N}$ content of nitrate would increase downstream, ultimately leading to increases in the $\delta^{15} \mathrm{~N}$ of successive biofilm samples. One interpretation of the patterns in Figure 10 is that nitrogen limitation drives the $\delta^{15} \mathrm{~N}$ of the biofilms to more and more positive values until just past the photosynthetic fringe, where a lighter nitrogen source is introduced to the system. This source of isotopically lighter $\mathrm{N}$ is potentially atmospheric $\mathrm{N}_{2}$, suggesting a dramatic shift in the $\mathrm{N}$ cycle of this hot spring ecosystem owing to nitrogen fixation by photosynthetic microorganisms. This scenario leads to two predictions. One of these is that assimilatory nitrate reduction occurs at the highest temperatures, and the other is that $\mathrm{N}_{2}$ fixation only occurs at or below the photosynthetic fringe, as this is the highest temperature location where biofilm $\delta^{15} \mathrm{~N}$ values show a decrease to zero. These predictions can be tested by searching for genes involved in $\mathrm{N}$ cycle processes.

\begin{tabular}{|l|c|c|c|c|c|}
\hline Gene & $\mathbf{5}$ & $\mathbf{4}$ & $\mathbf{3}$ & $\mathbf{2}$ & $\mathbf{1}$ \\
\hline NifH & $\mathbf{X}$ & $\mathbf{X}$ & & & \\
\hline NifD & $\mathrm{X}$ & $\mathbf{X}$ & & & \\
\hline NifK & & $\mathbf{X}$ & & & \\
\hline NifE & $\mathrm{X}$ & $\mathbf{X}$ & & & \\
\hline NifN & $\mathrm{X}$ & $\mathbf{X}$ & & & \\
\hline NifB & $\mathbf{X}$ & $\mathbf{X}$ & & & \\
\hline NifX & & $\mathbf{X}$ & & & \\
\hline NO$_{3}$-trans. & $\mathbf{X}$ & $\mathbf{X}$ & $\mathbf{X}$ & $\mathbf{X}$ & $\mathbf{X}$ \\
\hline Nas & $\mathbf{X}$ & $\mathbf{X}$ & & $\mathbf{X}$ & $\mathbf{X}$ \\
\hline Nir-assim. & $\mathbf{X}$ & $\mathbf{X}$ & $\mathbf{X}$ & $\mathbf{X}$ & $\mathbf{X}$ \\
\hline
\end{tabular}

Figure 11. Overall occurrence of nitrogen fixation and uptake indicators in "Bison Pool" communities 1-5 based on metagenome analysis. Cross, presence of the given gene; black, greater than 100,000 raw counts; gray, less than or equal to 100,000 raw counts. Genetic code abbreviations are NifH, dinitrogenase reductase; NifD, molybdenum dinitrogenase; NifK, molybdenum dinitrogenase; NifE, dinitrogenasebinding complex; NifN, molybdenum-iron nitrogenase cofactor; NifB, nitrogenase cofactor; NifX, nitrogenase fixation cofactor; NO3-trans., nitrate transport; Nas, assimilatory nitrate reductase; Nir, Nitrite reductase (assimilatory). 
[32] Metagenomic analysis permits searching for genes coding for specific proteins and protein subunits known to be involved with various steps of the nitrogen cycle. As shown in Figure 11, genes involved in nitrate transport, as well as assimilatory nitrate and nitrite reductase genes, are present throughout the microbial ecosystem. It can also be seen in Figure 11 that there is a striking difference between results for biofilms before the photosynthetic fringe, where there is no evidence for nitrogen fixation genes, and biofilms beyond the photosynthetic fringe (between sites 3 and 4), where abundant evidence for nitrogen fixation potential exists (genes from the nitrogenase or Nif operon). As a consequence, the metagenomic data are consistent with the isotopic composition of $\mathrm{N}$ in the biofilms and the assessment that nitrogen fixation is limited to the photosynthetic regions of the outflow channel.

\section{Concluding Remarks}

[33] Isotopic analysis of biofilms from "Bison Pool" shows that, even within a single hot spring system, there is an inherent ecological complexity among biofilms existing at different locations that are closely associated. Coupling the isotopic measurements with published data and metagenomic analysis allows us to predict the carbon fixation pathways that are creating the biofilm signatures and to illustrate the possibility of nitrogen limitation through the chemotrophic zone and nitrogen fixation in the lower temperature phototrophic zone.

[34] It is hoped that this effort to couple carbon and nitrogen isotopic values with metagenomic analyses provides a foundation for additional studies that can elucidate and constrain how biofilm communities adjust to seasonal changes and the resulting alterations in physical and geochemical parameters and how biofilm communities evolve over many years in response to gradual shifts in geochemical and geologic stresses. As a continuously flowing, siliceous sinter depositing hot spring "Bison Pool" serves as an initial starting point for the study of the $\mathrm{C}$ and $\mathrm{N}$ cycles in other hot springs. It remains to be seen whether hot springs of similar geochemical composition support biofilms with genetically equivalent communities producing isotopic compositions like those observed at "Bison Pool" or whether microbial communities in hot springs are as genetically unique and diverse as macrobiology on isolated islands and thus express unique and differing isotopic compositions.

[35] These results may also shed light on the very presence of biofilms in hot springs. If nitrogen limitation is common for higher temperature chemotrophic biofilms, then the presence of filaments in chemotrophic zones may be an indicator of nitrogen limitation, with biofilms producing copious exopolysaccharides and depositing silica in order to increase their exposure to limited resources as aqueous solutes or particulates. The discovery of $\mathrm{N}$ fixation at temperatures as high as $92^{\circ} \mathrm{C}$ in deep-sea hydrothermal vents [Mehta and Baross, 2006] should also provide a cautionary reminder that there may be other factors that may limit nitrogen fixation in terrestrial systems.

[36] Acknowledgments. This research was funded in part by NSF grant EAR-0525561 and JGI user agreement SHOCK 182 051129. The authors wish to thank the many participants in GEOPIG field campaigns in Yellowstone, particularly Jessica Havig, Brandon McLean, Nathan Schnebly, Katie Alexander, Maggie Osburn, Stan Klonowski, Hilairy Hartnett, Tracy Lund, Christopher Glein, Doug Laroe, Alycia Cox, and Kaitlyn Cox whose hard work was essential to the success of this project and is greatly appreciated. The authors also wish to acknowledge Mona Hwang for assisting with extracting DNA and Michael Thelen for the use of his facilities.

\section{References}

Barns, S. M., R. E. Fundyga, M. W. Jefferies, and N. R. Pace (1994), Remarkable archaeal diversity detected in a Yellowstone National Park hot spring environment, Proc. Natl. Acad. Sci. U. S. A., 91, 1609-1613. Beh, M., G. Strauss, R. Huber, K. Stetter, and G. Fuchs (1993), Enzymes of the reductive citric acid cycle in the autotrophic eubacterium Aquifex pyrophilus and the archaebacterium Thermoproteus neutrophilus, Arch. Microbiol., 160, 306-311.

Blank, C. E., S. L. Cady, and N. R. Pace (2002), Microbial composition of near-boiling silica-depositing thermal springs throughout Yellowstone National Park, Appl. Environ. Microbiol., 68, 5123-5135, doi:10.1128/ AEM.68.10.5123-5135.2002

Boyd, E. S., W. D. Leavitt, and G. G. Geesey (2009), $\mathrm{CO}_{2}$ uptake and fixation by a thermoacidophilic microbial community attached to precipitated sulfur in a geothermal spring, Appl. Environ. Microbiol., 75, 4289-4296, doi:10.1128/AEM.02751-08.

Brock, T. D. (1978), Thermophilic Microorganisms and Life at High Temperatures, 465 pp., Springer, New York.

Castenholz, R. W. (1969), Thermophilic blue-green algae and the thermal environment, Bacteriol. Rev., 33, 476-504.

Christiansen, R. L. (2001), The Quarternary and Pliocene Yellowstone Plateau volcanic field of Wyoming, Idaho, and Montana, U.S. Geol. Surv. Prof. Pap. 729-G, Menlo Park, Calif.

De Brabandere, L., T. K. Frazer, and J. P. Montoya (2007), Stable nitrogen isotope ratios of macrophytes and associated periphyton along a nitrate gradient in two subtropical, spring-fed streams, Freshwater Biol., 52, 1564-1575, doi:10.1111/j.1365-2427.2007.01788.x.

Estep, M. L. F. (1984), Carbon and hydrogen isotopic compositions of algae and bacteria from hydrothermal environments, Yellowstone National Park, Geochim. Cosmochim. Acta, 48, 591-599.

Estep, M. L. F., and S. A. Macko (1984), Nitrogen isotope biogeochemistry of thermal springs, Org. Geochem., 6, 779-785.

Ferris, M. J., G. Muyzer, and D. M. Ward (1996), Denaturing gradient gel electrophoresis profiles of $16 \mathrm{~S}$ rRNA-defined populations inhabiting a hot spring microbial mat community, Appl. Environ. Microbiol., 62, 340-346.

Hall, J. R., K. R. Mitchell, O. Jackson-Weaver, A. S. Kooser, B. R. Cron, L. J. Crossey, and C. D. Takacs-Vesbach (2008), Molecular characterization of the diversity and distribution of a thermal spring microbial community by using rRNA and metabolic genes, Appl. Environ. Microbiol., 74, 4910-4922, doi:10.1128/AEM.00233-08.

Havig, J. R. (2009), Geochemistry of hydrothermal biofilms: Composition of biofilms in siliceous sinter-depositing hot springs, doctoral dissertation, School of Earth and Space Exploration, Ariz. State Univ., Tempe.

House, C. H., J. W. Schopf, and K. O. Stetter (2003), Carbon isotopic fractionation by Archaeans and other hyperthermophilic prokaryotes, Org. Geochem., 34, 345-356.

Huber, R., W. Eder, S. Heldwein, G. Wanner, H. Huber, R. Rachel, and K. O. Stetter (1998), Thermocrinis ruber gen. nov., sp. nov., a pinkfilament-forming hyperthermophilic bacterium isolated from Yellowstone National Park, Appl. Environ. Microbiol., 64, 3576-3583.

Hugler, M., H. Huber, S. J. Molyneaux, C. Vetriani, and S. M. Sievert (2007), Autotrophic $\mathrm{CO}_{2}$ fixation via the reductive tricarboxylic acid cycle in different lineages within the phylum Aquificae: Evidence for two ways to citrate cleavage, Environ. Microbiol., 9, 81-92, doi:10.1111/ j.1462-2920.2006.01118.x.

Jahnke, L. L., W. Eder, R. Huber, J. M. Hope, K. Hinrichs, J. M. Hayes, D. J. des Marais, S. L. Cady, and R. E. Summons (2001), Signature lipids and stable carbon isotope analysis of Octopus Spring hyperthermophilic communities compared with those of Aquificales representatives, Appl. Environ. Microbiol., 67, 5179-5189, doi:10.1128/AEM.67.11.51795189.2001.

Jefferson, K. K. (2004), What drives bacteria to produce a biofilm?, FEMS Microbiol. Lett., 236, 163-173, doi:10.1016/j.femsle.2004.06.005.

Justice, S. S., D. A. Hunstad, L. Cegelski, and S. J. Hultgren (2008), Morphological plasticity as a bacterial survival strategy, Nat. Rev. Microbiol., 6, 162-168, doi:10.1038/nrmicro1820.

Macko, S. A., and M. L. F. Estep (1984), Microbial alteration of stable nitrogen and carbon isotopic compositions of organic matter, Org. Geochem., 6, 787-790. 
Madigan, M. T., R. Takigiku, R. G. Lee, H. Gest, and J. M. Hayes (1989), Carbon itotope fractionation by thermophilic phototrophic sulfur bacteria: Evidence for autotrophic growth in natural populations, Appl. Environ. Microbiol., 55, 639-644.

Mehta, M. P., and J. A. Baross (2006), Nitrogen fixation at $92^{\circ} \mathrm{C}$ by a hydrothermal vent Archaeon, Science, 314, 1783-1786, doi:10.1126/ science. 1134772.

Meyer-Dombard, D. R., E. L. Shock, and J. P. Amend (2005), Archaeal and bacterial communities in geochemically diverse hot springs of Yellowstone National Park, USA, Geobiology, 3, 211-227.

Mizutani, H., and E. Wada (1982), Effect of high atmospheric $\mathrm{CO}_{2}$ concentration on Delta-C-13 of Algae-A possible cause for the average depletion of $\mathrm{C}-13$ in Precambrian reduced carbon, Origin. Life Evol. Biosphere, 12, 377-390.

Needoba, J. A., D. M. Sigman, and P. J. Harrison (2004), The mechanism of isotope fractionation during algal nitrate assimilation as illuminated by the ${ }^{15} \mathrm{~N} /{ }^{14} \mathrm{~N}$ of intracellular nitrate, J. Phycol., 40, 517-522, doi:10.1111/ j.1529-8817.2004.03172.x.

Nikolaev, Yu. A., and V. K. Plakunov (2007), Biofilm-“City of Microbes" or an analogue of multicellular organisms?, Microbiology, 76, 125-138, doi:10.1134/S0026261707020014.

Northen, T. R., J.-C. Lee, L. Hoang, J. Raymond, D.-R. Hwang, S. M. Yannone, C.-H. Wong, and G. Siuzdak (2008), A nanostructure-initiator mass spectrometry-based enzyme activity assay, Proc. Natl. Acad. Sci. U. S. A., 105, 3678-3683, doi:10.1073/pnas.0712332105.

Pardue, J. W., R. S. Scalan, C. Vanbaalen, and P. L. Parker (1976), Maximum carbon isotope fractionation in photosynthesis by blue-green-algae and a green-algae, Geochim. Cosmochim. Acta, 40, 309-312.

Preuss, A., R. Schauder, G. Fuchs, and W. Stichler (1989), Carbon isotope fractionation by autotrophic bacteria with 3 different $\mathrm{CO}_{2}$ fixation pathways, Z. Naturforsch., 44, 397-402.

Pulcini, E. D. (2001), Bacterial biofilms: A review of current research, Nephrologie, 22, 439-441.

Raymond, J. (2005), The evolution of biological carbon and nitrogen cycling-A genomic Perspective, Rev. Min. Geochem., 59, 211-231, doi:10.2138/rmg.2005.59.9.

Reysenbach, A.-L., and S. L. Cady (2001), Microbiology of ancient and modern hydrothermal systems, Trends Microbiol., 9, 79-86.

Reysenbach, A.-L., M. Ehringer, and K. Hershberger (2000), Microbial diversity at $83^{\circ} \mathrm{C}$ in Calcite Springs, Yellowstone National Park: Another environment where the Aquificales and "Korarchaeota" coexist, Extremophiles, 4, 61-67, doi:10.1007/s007920050008.

Robertson, C. E., J. K. Harris, J. R. Spear, and N. R. Pace (2005), Phylogenetic diversity and ecology on environmental Arcaea, Curr. Opin. Microbiol., 8, 638-642, doi:10.1016/j.mib.2005.10.003.

Shiba, H., T. Kawasumi, Y. Igarashi, T. Kodama, and Y. Minoda (1985), The $\mathrm{CO}_{2}$ assimilation via the reductive tricarboxylic acid cycle in an obligately autotrophic, aerobic hydrogen-oxidizing bacterium, Hydrogenobacter thermophilus, Arch. Microbiol., 141, 198-203.

Shock, E. L., M. E. Holland, D. R. Meyer-Dombard, J. P. Amend G. R. Osburn, and T. Fisher (2010), Quantifying inorganic sources of geochemical energy in hydrothermal ecosystems, Yellowstone National Park, USA, Geochim. Cosmochim. Acta, 74, 4005-4043.

Stahl, D. A., D. J. Lane, G. J. Olsen, and N. R. Pace (1985), Characterization of a Yellowstone hot spring microbial community by $5 \mathrm{~S}$ rRNA sequences, Appl. Environ. Microbiol., 49, 1379-1384.

Steunou, A., D. Bhaya, M. M. Bateson, M. C. Melendrez, D. M. Ward, E. Brecht, J. W. Peters, M. Kuhl, and A. R. Grossman (2006), In situ analysis of nitrogen fixation and metabolic switching in unicellular thermophilic cyanobacteria inhabiting hot spring microbial mats, Proc. Natl. Acad. Sci. U. S. A., 103, 2398-2403, doi:10.1073/pnas.0507513103.

Takacs-Vesbach, C., K. Mitchell, O. Jackson-Weaver, and A. Reysenbach (2008), Volcanic calderas delineate biogeographic provinces among
Yellowstone thermophiles, Environ. Microbiol., 10, 1681-1689, doi:10.1111/j.1462-2920.2008.01584.x.

van der Meer, M. T. J., S. Schouten, J. W. de Leeuw, and D. W. Ward (2000a), Autotrophy of green nonsulfur bacteria in hot spring microbial mats: Biological explanations for isotopically heavy organic carbon in the geological record, Environ. Microbiol., 2, 428-435.

van der Meer, M. T. J., S. Schouten, W. I. C. Rijpstra, G. Fuchs, and J. S. S. Damste (2000b), Stable carbon isotope fractionations of the hyperthermophilic crenarchaeon Metallosphaera sedula, FEMS Microbiol. Lett., 196, 67-70.

van der Meer, M. T. J., S. Schouten, J. S. S. Damste, J. W. de Leeuw, and D. W. Ward (2003), Compound-specific isotopic fractionation patterns suggest different carbon metabolisms among chloroflexus-like bacteria in hot-spring microbial mats, Appl. Environ. Microbiol., 69, 60006006, doi:10.1128/AEM.69.10.6000-6006.2003.

van der Meer, M. T. J., S. Schouten, M. M. Bateson, U. Nubel, A. Wieland, M. Kuhl, J. W. de Leeuw, J. S. S. Damste, and D. M. Ward (2005), Diel variations in carbon metabolism by green nonsulfur-like bacteria in alkaline siliceous hot spring microbial mats from Yellowstone National Park, Appl. Environ. Microbiol., 71, 3978-3986, doi:10.1128) AEM.71.7.3978-3986.2005.

van der Meer, M. T. J., S. Schouten, J. S. S. Damste, and D. M. Ward (2007), Impact of carbon metabolism on 13C signatures of cyanobacteria and green non-sulfur-like bacteria inhabiting a microbial mat from an alkaline siliceous hot spring in Yellowstone National Park (USA), Environ. Microbiol., 9, 482-491, doi:10.111/j.1462-2920.2006.01165.x. Ward, D. M., M. M. Bateson, M. J. Ferris, M. Kuhl, A. Wieland, A. Koeppel, and F. M. Cohan (2006), Cyanobacterial ecotypes in the microbial mat community of Mushroom Spring (Yellowstone National Park, Wyoming) as species-like units linking microbial community composition, structure and function, Philos. Trans. R. Soc. B, 361, 1997-2008, doi:10.1098/ rstb.2006.1919.

Waser, N. A. D., P. J. Harrison, B. Nielson, S. E. Calvert, and D. H. Turpin (1998), Nitrogen isotope fractionation during the uptake and assimilation of nitrate, nitrite, ammonium, and urea by a marine diatom, Limnol. Oceanogr., 43, 215-224.

Watnick, P., and R. Kolter (2000), Biofilm, City of Microbes, J. Bacteriol., $182,2675-2679$.

Wickstrom, C. E. (1980), Distribution and physiological determinants of blue-green algal nitrogen fixation along a thermogradient, J. Phycol., $16,436-443$.

Windman, T., N. Zolotova, F. Schwandner, and E. L. Shock (2007), Formate as an energy source for microbial metabolism in chemosynthetic zones of hydrothermal ecosystems, Astrobiology, 7, 873-890, doi:10.1089/ ast.2007.0127.

Zhang, C. L., et al. (2002), Carbon isotopic fractionations associated with thermophilic bacteria Thermotoga maritima and Persephonella marina, Environ. Microbiol., 4, 58-64.

Zhang, C. L., B. W. Fouke, G. T. Bonheyo, A. D. Peacock, D. C. White, Y. Huang, and C. S. Romanek (2004), Lipid biomarkers and carbonisotopes of modern travertine deposits (Yellowstone National Park, USA): Implications for biogeochemical dynamics in hot-spring systems, Geochim. Cosmochim. Acta, 68, 3157-3169, doi:10.1016/j.gca. 2004.03.005.

J. R. Havig, E. L. Shock, and N. Zolotova, School of Earth and Space Exploration, Arizona State University, Tempe, AZ 85287-1404, USA. (jeff.havig@asu.edu)

D. R. Meyer-Dombard, Department of Earth and Environmental Sciences, University of Illinois at Chicago, Chicago, IL 60607-7059, USA.

J. Raymond, School of Natural Sciences, University of California, Merced, CA 95343, USA. 